\title{
Archipel
}

ARCHIPEL Études interdisciplinaires sur le monde insulindien

\section{5 | 2018}

Varia

\section{Kekerasan Kemanusiaan dan Perampasan Tanah Pasca- 1965 di Banyuwangi, Jawa Timur}

Les violences aux personnes et les saisies de terres post-1965 à Banyuwangi, Java Est

\section{Ahmad Nashih Luthfi}

\section{OpenEdition}

\section{Journals}

Édition électronique

URL : https://journals.openedition.org/archipel/624

DOI : $10.4000 /$ archipel.624

ISSN : 2104-3655

Éditeur

Association Archipel

Édition imprimée

Date de publication : 29 juin 2018

Pagination : 53-86

ISBN : 978-2-910513-79-5

ISSN : 0044-8613

\section{Référence électronique}

Ahmad Nashih Luthfi, « Kekerasan Kemanusiaan dan Perampasan Tanah Pasca- 1965 di Banyuwangi, Jawa Timur », Archipel [En ligne], 95 | 2018, mis en ligne le 01 juillet 2018, consulté le 21 septembre 2021. URL : http://journals.openedition.org/archipel/624 ; DOI : https://doi.org/10.4000/archipel.624 


\section{Kekerasan Kemanusiaan dan Perampasan Tanah Pasca- 1965 di Banyuwangi, Jawa Timur}

\section{Pendahuluan}

Pelaksanaan Land reform tahun 1960-an bertujuan melahirkan kelas pemilik tanah baru dan memperbaiki ketimpangan agraria. Ia bersifat re-distributif, yakni mengambil terlebih dahulu tanah kelebihan maksimum atau absentee ${ }^{3}$, lalu membagikannya kembali kepada para petani tuna kisma; serta pengalokasian tanah bekas perkebunan Belanda yang telah diduduki rakyat. Tanah negara hanya bersifat menambahi kekurangan yang ada di suatu wilayah, sebab tujuan utamanya adalah merombak ketimpangan struktur agraria yang ada di tengah-tengah masyarakat.

Sejarah pelaksanaan Land reform yang disusul dengan counter-Land reform di Indonesia berhimpitan dengan sejarah kekerasan. Umumnya para sejarawan menyajikannya secara kronologis bahwa aksi sepihak untuk mempercepat pelaksanaan Land reform adalah prolog yang dilakukan oleh PKI/BTI dan simpatisannya; peristiwa penculikan para jenderal pada malam 30 September 1965 sebagai nalog, yaitu peristiwa utamanya, dan penumpasan oleh militer dan sipil terhadap pengikut PKI adalah epilog-nya (Notosusanto 1989; Kasdi

1. Pengajar di Sekolah Tinggi Pertanahan Nasional, Yogyakarta, dan editor di Etnohistori.

2. Penulis mengucapkan terima kasih kepada Moh. Shohibuddin atas berbagai saran perbaikan, Ariesti Putri Anggriana yang membantu dalam penyediaan data, Elsa Clavé yang memungkinkan naskah awal ini didiskusikan dalam konferensi di Frankfurt University, serta Sekolah Tinggi Pertanahan Nasional yang memungkinkan penelitian ini dikerjakan.

3. Tanah absentee adalah tanah yang pemiliknya absen atau berada di luar kecamatan di mana tanah tersebut berada. 
2001, 2011; Sulistyo 2000). Di beberapa tempat, kekerasan pasca-1965 tampak berbanding lurus dengan radikalisme dan kesuksesan kampanye Land reform pada tahun 1963-1965 (Robinson 2006: 415). Ini berlaku terutama di wilayah dengan sasaran obyek Land reform berupa tanah milik, sehingga terjadi perjuangan antar-kelas dalam masyarakat agraris di pedesaan.

Tulisan ini berfokus pada kaitan antara kekerasan 1965 dengan persoalan agraria di Banyuwangi, Jawa Timur, yang membantah historiografi sejarah agraria di Indonesia selama ini yang berpendirian bahwa kekerasan disebabkan oleh konflik pedesaan-horisontal yang telah ada sebelumnya dan yang eskalatif dengan dilaksanakannya Land reform dan berbagai "aksi sepihak". Dalam kenyataannya, kekerasan juga terjadi di wilayah perkebunan yang bersifat vertikal (perusahaan perkebunan dengan rakyat) yang notabene bukan perkebunan aktif namun telah diterlantarkan atau bekas tanah erfpacht ${ }^{4}$ Belanda yang sudah diduduki rakyat sejak lama.

Artikel ini meneliti kekerasan itu dalam perspektif waktu panjang (longue durée) dan menunjukkan bahwa kejadian dalam sejarah agraria itu bisa dibaca sebagai peristiwa yang bertujuan pada akumulasi kapital, sebuah ciri yang menjadi bagian integral dari pembangunan politik dan ekonomi (perkebunan) Orde Baru selanjutnya. Tesis utama ini didasarkan pada bukti-bukti yang terjadi di Banyuwangi pasca-1965 dan pemeriksaan sumber primer yang berasal dari dokumen resmi militer ${ }^{5}$ dan kantor pertanahan.

Saya akan memulai dengan pengantar dilanjutkan dengan tinjauan konseptual yang menempatkan isu kekerasan dan tanah sebagai bagian dari "akumulasi primitif". Bagian berikutnya mendeskripsikan pelaksanaan Land reform di Indonesia dan di tingkatan lokal Banyuwangi, serta arti pentingnya bagi perbaikan struktur agraria lokal. Lalu saya menyajikan kekerasan-kekerasan yang mengakibatkan jatuhnya korban yang dilakukan oleh militer dan sipil, penghitungan angka korban dari berbagai kecamatan di Banyuwangi, serta pembacaan secara kritis dokumen yang digunakan dalam membangun narasi. Bagian keempat adalah bentuk-bentuk perampasan kembali tanah oleh berbagai aktor secara vertikal maupun horisontal. Juga adanya upaya organisasi tani, Pertanu (Pertanian Nahdlatul Ulama) dan Petani (Petani Nasionalis Indonesia), melawan ancaman counter-Land reform. Kaitan antara kekerasan dengan perampasan-kembali yang menjadi inti dari tesis tulisan ada di bagian ini. Pada bagian penutup, saya membuat kesimpulan dan refleksi singkat bagi pengkajian sejarah agraria dan sejarah Indonesia 1965.

4. Erfpacht, atau eerfelijke pacht, adalah hak sewa untuk tanah perkebunan.

5. Dokumen militer ini sekarang dikelola oleh Etnohistori (disingkat EHO), dengan kode: Arsip EHO. 


\section{Kekerasan sebagai "akumulasi primitif"}

Sejarah Landreform adalah sejarah naik-turunnya perebutan sumber-sumber produksi (tanah-air Indonesia) antara kepentingan nasional dan masyarakat, dan kepentingan kapital(isme) nasional/global. Bisa dibaca sejak monopoli sumberdaya agraria pada masa perkebunan kolonial, reklaiming tanah-tanah perkebunan oleh perjuangan rakyat pada masa Jepang, hingga usaha Indonesia melakukan dekolonisasi ekonomi, dengan dinamika dikuasainya sektor ekonomi strategis berupa perkebunan oleh militer melalui adanya UndangUndang Darurat pada tahun 1953. Usaha dekolonisasi dan defeodalisasi tidak berhenti di sini. Pemerintah melakukan nasionalisasi perkebunan Eropa pada tahun 1958, dan dimantapkan dengan lahirnya Undang-Undang Pokok Agraria tahun 1960, disusul dengan Peraturan Pengganti UU Nomor 56 tahun 1961 tentang penetapan luas tanah pertanian atau lebih dikenal dengan UU Land reform.

Rangkaian sejarah panjang itu (longue durée) berada dalam konteks pertumbuhan dan perluasan kapitalisme agraria di wilayah Indonesia serta perjuangan pemerintah nasional dan rakyat melakukan perlawanan terhadap ekspansi tersebut (Luthfi, Razif, dan Fauzi 2011: 1-10). Jika demikian maka kekerasan 1965 bukan "konsekuensi" yang harus diterima oleh rakyat atas tindakan-tindakan (sepihak) yang mereka lakukan sebelumnya, namun justru penumpasan itu merupakan tonggak baru dari pelanjutan dan perluasan kapital yang mengalami interupsi melalui kebijakan nasionalisasi dan Land reform tersebut. Ia adalah akumulasi primitif bagi roda kapitalisme, "suatu akumulasi yang bukan hasil cara produksi kapitalis melainkan adalah titik berangkatnya" (Marx 2004). Arus balik ekspansi kapital justru terjadi pasca1965, dan pembunuhan adalah proses brutal yang memberi jalan lempang bagi perluasan tersebut.

Saya menggunakan konsep "akumulasi primitif" dari Karl Marx untuk membaca hubungan kekerasan kemanusiaan 1965 dengan pengambilalihan tanah-tanah rakyat.

Sebelum studi ini, perlu disebutkan kajian Hilmar Farid (2005) yang mengaitkan keduanya dengan penjelasan yang bersifat makro (Farid 2005, 2013). Apa yang saya sajikan ini memberikan penjelasan dengan bukti dan konteks lokal.

Sebagaimana dijelaskan di depan rakyat tani memperoleh tanah dan ruang hidupnya melalui perjuangan. Kebijakan Land reform tahun 1960-an memberi harapan besar. Akan tetapi tatkala tanah-tanah diambil-alih kembali dan tubuhtubuh manusia dibinasakan, maka mereka yang berhasil selamat selain mendapat stigma, masuk ke dalam kerangka hubungan kerja baru yang ditentukan oleh upah. Terjadi proses pemisahan sosial dan pemisahan produksi. ${ }^{6}$

6. Marx menjelaskan dari pengalaman di Inggris abad ke-17, bahwa "proses besar terakhir perampasan tanah dari penduduk pertanian adalah, pada akhirnya, yang dinamakan "pembersihan 
Pada era berikutnya, pertumbuhan ekonomi yang mendapat sokongan penuh Amerika Serikat dan kebijakan transmigrasi masa Orde Baru mendorong para bekas petani ini menjadi tenaga kerja baru (buruh) di perkotaan dan pulau-pulau luar Jawa. ${ }^{7}$ Kekerasan, penghancuran benda-benda, perampasan tanah, tekanan dan pengusiran, hingga pembunuhan yang terjadi pada pengikut PKI atau yang dipersangkakan sebagai PKI, adalah bagian integral dari pembangunan ekonomi tersebut. Kekerasan ini tidak dilakukan secara spontan, namun di bawah komando militer. Indonesia bukanlah kasus yang khas di dunia. Ada banyak kudeta yang disertai banjir darah di Negara Selatan (Amerika Latin, Afrika, dan Asia) antara 1960 dan 1975 (Farid 2005: 4).

Konsep Tania M. Li tentang "letting die" menjelaskan dengan baik akibat kekerasan itu (Li 2009). Jika massacre adalah making die, maka proses yang terjadi setelahnya adalah letting die. "Menjadikan mati" dalam arti harfiah berarti pembunuhan, sedangkan dalam arti kiasan berarti mencerabut mereka dari sistem produksi, wilayah hidup tempatan, bahkan kewarganegaraannya. Akibat lanjutannya adalah surplus populasi yang tidak terserap dalam aktifitas produksi pedesaan ataupun non-pedesaan. Begitu seterusnya kebijakan yang tidak mengabsorbsi mereka, sama artinya membuat mereka mati. Ini kontras dengan kebijakan Land reform sebelumnya yang memiliki arti "making alive" bagi populasi pedesaan.

Pada bagian berikutnya ini saya akan menyajikan pelaksanaan Land reform dan bagaimana rangkaian kekerasan itu terjadi di Banyuwangi. Terlebih dahulu saya sajikan secara umum pelaksanaan Land reform di Indonesia.

tanah-tanah', yaitu penyapuan bersih makhluk-makhluk manusia dari tanah-tanah itu" (Marx 2004: 814). Jika tidak ingin mengalami krisis, maka kapital harus mereproduksi dalam lingkaran M-C-M (Money-Commodity-Money). Dalam konteks ini berarti, pembunuhan dilakukan untuk mendapatkan tanah, memperoleh tenaga kerja murah perkebunan/industrial yang terlepas dari pertanian, sehingga bisa mendapat kelebihan/akumulasi yang berkelanjutan.

7. Kajian Bradley R. Simpson menjelaskan bahwa terjadi konsolidasi kekuatan politik luar dan dalam negeri anti-Soekarno, serta pembangunan ekonomi Indonesia yang disokong secara penuh oleh Washington. Paket ekonomi, asistensi, pengiriman konsultan, dan berbagai bantuan triumvirat (kolaborasi antara pemerintah-tentara Amerika, pengusaha, dan ilmuwan) diberikan pada pemerintahan Soeharto, sehingga lahir kekuatan baru di Indonesia yang memberi peran sentral pada para ekonom didikan Amerika, militer, dan kaum teknokrat (Simpson 2008). Peristiwa politik luar-negeri lain yang sangat penting dalam puncak rezim Soeharto adalah diselenggarakannya konferensi tentang Indonesia di universitas hubungan internasional terkemuka, Fletcher School of Law and Diplomacy, Tuft University, Medford (Mass., US), 6-8 Oktober 1983. Pertemuan dihadiri oleh 300 orang dari Indonesia, utamanya teknokrat petinggi Orde Baru, untuk bertemu dengan para ilmuwan, petinggi Amerika dan pelaku bisnis di sana. Amerika sebagai super-power politik, militer, ekonomi, dan keilmuan, tidak terpisahkan dan memiliki arti penting bagi politik (pengetahuan) Indonesia (Tamara 1987). 


\section{Land reform di Indonesia dan aksi sepihak}

Ada kesenjangan antara konsensus di tingkat nasional dan lokal. Lahirnya Undang-Undang No. 2/1960 tentang Perjanjian Bagi Hasil (UUPBH), UU No. 5/1960 tentang Peraturan Dasar Pokok Pokok Agraria (UUPA) disusul dengan PerpU Nomor 56 tahun 1961 yang memandatkan pelaksanaan Land reform adalah konsensus nasional yang bersifat "jalan tengah". Keduanya produk kompromi dari perdebatan panjang di Parlemen antara kalangan nasionalis, agama, dan komunis. Di tingkat bawah terjadi radikalisasi pedesaan oleh kekuatan partai politik melalui saluran organisasi taninya masing-masing, seperti BTI (PKI), Petani (Partai Nasionalis Indonesia), dan Pertanu (Nahdlatul Ulama), dan lain-lain.

Produk hukum itu dianggap bukan komunis namun anti-feodalisme, serta menjamin hak milik namun ada batasan. Pasal 5 UUPA 1960 mencerminkan kompromi dan perpaduan ini, bahwa hukum agraria yang dirumuskan "ialah hukum adat", "berdasarkan atas persatuan bangsa", "dengan sosialisme Indonesia", dan "mengindahkan unsur-unsur yang bersandar pada hukum agama" (UUPA 1960). UUPA 1960 ini mengakui hak milik pribadi atas tanah, hak adat/komunal, dan hak yang bersumber dari sistem agama (wakaf dan waris). Singkatnya, gagasan Nasionalis Agama dan Komunis (Nasakom) tercermin dalam UU ini.

Infrastruktur kelembagaan juga disiapkan secara ketat. Lahir Keputusan Presiden No. 131 Tahun 1961 tentang Organisasi Penyelenggaraan Land reform. Dibentuk Panitia-panitia Land reform Pusat, Daerah Tingkat I, Daerah Tingkat II, Kecamatan dan Desa, yang bertugas menyelenggarakan pimpinan, pelaksanaan, pengawasan, bimbingan serta koordinasi (lintas sektor). Panitia Land reform pusat langsung dipimpin oleh Presiden. Badan Pekerja Panitia Land reform diketuai oleh Menteri Agraria. Guna memperlancar pembiayaan dan pemberian fasilitas kredit, pasal 16 PP No. 224 Tahun 1961 mewajibkan dibentuknya suatu badan hukum otonom berupa Yayasan Dana Land reform. Yayasan ini didirikan di Jakarta pada tanggal 25 Agustus 1961.

Meski telah demikian lengkap bangunan kelembagaan yang dibentuk, di tingkatan implementasi situasinya sangatlah berbeda. Ada ketidakmampuan pelaksana atau hambatan birokratis yang didinamisir oleh tuan tanah perdesaan dan beberapa sebab lain, sehingga mengakibatkan Land reform "matjet", gagal, dan selanjutnya mengalami stigmatisasi sebagai "cara-cara kuminis".

Oleh para petani yang tergabung dalam BTI (Barisan Tani Indonesia), tindakan tuan tanah dianggap melawan kebijakan nasional. Maka muncullah gerakan tani yang dikenal pada masa itu sebagai 'aksef' (aksi sefihak/ sepihak). Mereka merebut kembali tanah yang telah disewakan, mengambil lagi tanah yang telah digadaikan, meminta kembali tanah yang telah dijual, atau memanen padi di sawah tanpa sepengetahuan tuan tanah.

Istilah "sefihak" itu sendiri sebenarnya menyimpan persoalan, sebab yang 
terjadi adalah aksi "berbagai fihak". Masing-masing pihak melakukan tindakan pengamanan dan penyelamatan atas tanahnya. Mengutip ucapan resmi Presiden Soekarno yang saat itu sebagai Ketua Panitia Land reform Pusat,

"Lalu ada polemik tentang pelaksanaan UUPA-UUPBH, terutama tentang aksef (aksi sefihak) kaum tani [...] Maka dari itu saja perintahkan kepada sekalian pedjabat jang ada hubungannja dengan pelaksanaan UUPA untuk segera mengadakan perundingan 2 dengan kaum tani. [j]ang notabene bukan dengan tjuma-tjuma, tetapi dengan kompensasi jang harus dibajar oleh bapak-bapak dan ibu-ibu tani. Negara kita tidak merampas milik-tanah siapapun! Sedjengkalpun tak ada jang dirampas berdasarkan UUPA!" (Soekarno 1964: 210; 212-213).

Kekerasan 1965 selalu berkaitan dengan konteks lokal. Di Lampung, pembantaian dilakukan oleh penduduk Muslim setempat yang terganggu oleh para transmigran Jawa. Di Nusa Tenggara, ketegangan terjadi antara Kristen dan agamaagama setempat. Di Timor, gereja Protestan justru bersama petani miskin dalam masalah Land reform, yang akibatnya, para pendeta, guru, dan staf universitas menjadi target utama pembunuhan. Di Bali, ada persoalan mempertahankan Hinduisme, persaingan patronase, dan pembantaian oleh militer bersama milisi kelompok PNI (Tameng Marhaen). Sementara di Kalimantan Barat terjadi pada orang Tionghoa oleh suku Dayak (Cribb 2003: 44-46).

Konteks lokal yang ingin saya tunjukkan di sini adalah terganggunya kelas pemilik tanah pedesaan (horisontal, antar-masyarakat) dan pemegang konsesiatas tanah secara luas dalam bentuk erfpacht/Hak Guna Usaha perkebunan (vertikal, korporasi/negara dengan masyarakat) akibat dari pelaksanaan Land reform di Banyuwangi. Pembunuhan massal terjadi di lokasi-lokasi dilaksanakannya (re) distribusi tanah, baik di pedesaan (sawah) maupun di perkebunan.

\section{Land reform di Banyuwangi}

Land reform di Banyuwangi dijalankan terhadap kepemilikan tanah kelebihan maksimum (1.079,2 ha), tanah absentee (153,57 ha), dan tanah bekas perkebunan atau tanah negara (3.681,67 ha). Di Jawa Timur redistribusi terhadap tanah bekas perkebunan berdasarkan dua Surat Keputusan Menteri Agraria ${ }^{8}$ yang menyebutkan perkebunan mana saja yang ditetapkan sebagai obyek Land reform. Di Banyuwangi lima perkebunan yang menjadi sasaran dari 49 perkebunan yang ada saat itu, yakni: Perkebunan Sorangan/Karang Tambak, Kadisuro, Pesanggaran, Padang Bulan, dan Bangoredjo.

Sampai dengan tahun 1964, tanah yang berhasil diredistribusi di Banyuwangi adalah $4.914,5$ ha, berasal dari 421 orang bekas pemilik dan 10 eks-perusahaan / tanah negara. ${ }^{9}$ Jumlah petani penerimanya adalah 13.781

\section{SK. 49/KA/64 dan SK. 50/KA/64.}

9. Diolah dari data tiga kategori tersebut, Kantor Pertanahan Banyuwangi, Register Land reform Kantor Pertanahan Banyuwangi. Ini merupakan buku register yang terus diperbarui yang mencatat pelaksanaan Land reform di Banyuwangi sejak tahun 1964. Catatan perkembangan pelaksanaan Land reform terus ditambahkan, seperti informasi mengenai perkembangan 
orang. Secara nasional, tahap pertama sd. 1964 (meliputi Jawa, Madura dan Sunda Kecil) tercapai angka 294.500 ha tanah (termasuk tanah eks-swapraja, yaitu nasional) yang berhasil diredistribusi dari target 337.445 hektar. Sedangkan untuk Jawa Timur, terdapat 22.342 ha tanah kelebihan maksimum yang terdata sebagai Tanah Obyek Land reform (TOL) (dari 65.132 ha di Indonesia). Angka dari kategori lain sayangnya tidak diketahui.

Tabel 1 - Hasil Redistribusi Tanah Program Land reform (dalam hektar)

\begin{tabular}{|c|c|c|c|c|c|c|}
\hline \multirow[b]{2}{*}{ Kelebihan Maksimum } & \multirow{2}{*}{$\begin{array}{c}\begin{array}{c}\text { Indonesia } \\
\text { (tahap I) }^{\mathbf{1 0}}\end{array} \\
65.132\end{array}$} & \multicolumn{2}{|c|}{ Jawa Timur ${ }^{11}$} & \multicolumn{3}{|c|}{ Banyuwangi $^{12}$} \\
\hline & & 22.342 & $34,3 \%$ & $\begin{array}{l}1.079,2 \\
(22 \%)\end{array}$ & $1,6 \%$ & $4,8 \%$ \\
\hline Absentee & 18.421 & & & $\begin{array}{c}153,57 \\
(3 \%)\end{array}$ & \multicolumn{2}{|c|}{$0,83 \%$} \\
\hline $\begin{array}{l}\text { Hak Guna Usaha/ } \\
\text { Tanah Negara }\end{array}$ & 147.192 & & & $\begin{array}{c}3.681,67 \\
(75 \%) \\
\end{array}$ & \multicolumn{2}{|c|}{$2,5 \%$} \\
\hline Jumlah & $\begin{array}{c}230.745 \text { (tidak terma- } \\
\text { suk tanah eks-swapraja) }\end{array}$ & & & $4.914,5$ & \multicolumn{2}{|c|}{$2,12 \%$} \\
\hline
\end{tabular}

Land reform di Banyuwangi menyumbang 1,6\% terhadap nasional atau 4,8\% terhadap Jawa Timur. Capaian ini tergolong kecil mengingat Banyuwangi adalah kabupaten dengan wilayah terluas di Jawa Timur, dan memiliki perkebunan terbanyak (49 perusahaan) disusul Jember (26 perusahaan) (Ismet 1970: 191-197). Menarik untuk dicatat bahwa Land reform di sini secara umum mengoreksi ketimpangan agraris yang ada di sekitar perkebunan. Dua pertiga obyek tanah Land reform adalah tanah bekas perkebunan, dan sepertiganya adalah tanah milik kelas dominan pedesaan.

Oleh karena itulah untuk mempercepat dan memperluas pelaksanaan Land reform di Banyuwangi, selain adanya kemacetan berbagai sebab sebagaimana dijelaskan di muka, maka terjadi aksi-aksi sepihak lanjutan. Aksi bukan hanya dilakukan oleh BTI namun berbagai unsur PKI yang ada di dalamnya. Semula hanya aksi-aksi yang bertujuan menekan panitia dan boikot tanah berkembang di lapangan ketika terjadi penyelewengan, pengalihan tanah, dan perlawanan dari pemilik. Terjadilah apa yang saat itu di Banyuwangi disebut dengan "royokan tanah" (saling memperebutkan tanah) yang disertai perusakan rumah dll. ${ }^{13}$ Kedua belah pihak saling mempertahankan posisinya.

pembayaran ganti rugi dan terbitnya sertifikat tanah yang dibagikan.

10. Achdian 2008: 74.

11. Anonim 1964: 156 .

12. Diolah dari tiga buku induk Land reform Kantor Pertanahan Banyuwangi: Register Bekas Pemilik Tanah Kelebihan, tanpa tahun A; Register Land reform Kantor Pertanahan Banyuwangi, tanpa tahun B; Register Bekas Tanah Negara, tanpa tahun C.

13. Keterangan dari Pak Ichwan, sekretaris NU Banyuwangi era 1980-an yang pada tahun 1964 
Tidak keseluruhan unsur PKI setuju dengan tindakan tersebut, mencerminkan bahwa ia dilakukan secara spontan tanpa komando terpusat, namun sangat ditentukan oleh situasi lapangan. ${ }^{14}$ Misalnya aksi sepihak yang terjadi di Glenmore terhadap sekitar 4 hektar tanah guntai berupa kebun kelapa yang dimiliki oleh orang yang tinggal di Jakarta dan kebun tersebut diserahkan pengelolaannya kepada salah seorang kepala sekolah SD, sehingga menyulitkan eksekusi redistribusi. Para pelaku aksi "merontoki" buah kelapa yang masih di atas pohon. Unsur anggota PKI lainnya, semisal Pemuda Rakyat ${ }^{15}$, setidak-tidaknya yang disuarakan oleh wakil ketuanya, tidak membenarkan aksi tersebut. ${ }^{16}$

Awal Juli 1964 sejumlah 22 gabungan organisasi di bawah PKI Banyuwangi menuntut pertanggungjawaban kemacetan pelaksanaan UUPBH dan UUPA. Aksi mendapat tentangan dari Pertanu dan Petani. Jika ingin menyukseskan pelaksanaan Land reform, istilah mereka, harus "hand to hand", bergandengan tangan dan bukan dengan melakukan aksi sepihak. Di Jawa Timur aksi sepihak memang meluas (Antara 1965; Mustafa 2015: 54). Menteri Kompartemen Pertanian dan Agraria, Sadjarwo S.H., berkunjung ke Jawa Timur untuk meredakan itu dan menegaskan agar unsur Nasakom tetap bersatu (Antara 1965).

Aksi-aksi sepihak masih terjadi bahkan setelah Deklarasi Bogor berlangsung pada 12 Desember 1964. Sukarno memanggil semua pimpinan partai ke Bogor dan memerintahkan agar semuanya menahan diri dari berbagai ketegangan di pedesaan saat itu. Ia melihat bahwa tindakan masing-masing pihak dalam mengamankan posisinya berbuntut kekacauan di pedesaan. Meski demikian, di tingkat lokal, deklarasi itu ternyata tidak cukup ampuh. Masih saja di Banyuwangi terjadi letupan-letupan sporadis. Pejabat Land reform Pusat akhirnya turun ke Banyuwangi untuk melakukan pendataan dan memerintahkan agar semua unsur menghentikan tindakan-tindakan di luar mekanisme Panitia. Hasil catatan yang dikumpulkan pejabat tersebut

baru datang ke Banyuwangi dari Jember dan menyaksikan aksi royokan tersebut. Wawancara di Srono, 5 Oktober 2016.

14. Sekali digelindingkan, Land reform mengambil momentumnya sendiri. Secara internal antara PKI dengan BTI sendiri tidak satu suara. Aksi-aksi lokal yang dilakukan BTI dalam perkembangannya dinilai merugikan reputasi PKI di tingkat pusat, meski PKI pada mulanya sejak medio 1963 menjadikan Land reform sebagai isu resmi kampanye. Oleh karena itu, Deklarasi Bogor membuat PKI, dalam istilah Mortimer, lega dengan hasil kesepakatan yang dihasilkan (Robinson 2006: 403).

15. Pemuda Rakyat, Lekra, Gerakan Wanita Indonesia (Gerwani), Himpunan Sarjana Indonesia (HSI), dan Concentrasi Gerakan Mahasiswa Indonesia (CGMI) tidak serta merta memiliki kaitan langsung dengan PKI. Untuk meringkas kerumitan hubungan ini, Saskia Wieringa menyebutnya sebagai "Keluarga Komunis" (Wieringa 1999: xxxix).

16. Penjelasan dari Bambang Ruswanto, Ketua II Pemuda Rakyat Banyuwangi (1963) dan Anggota Dewan Harian Pemuda Rakyat Jawa Timur (1964-1965). Bahkan ia menolak ketika diminta untuk me-neken persetujuan aksi sepihak, saat di mana secara nasional justru tekanan aksi yang lebih progresif dipidatokan sendiri oleh Aidit. Wawancara Bambang Ruswanto, Genteng, 5 Oktober 2016. 
menyebutkan bahwa ada aksi sepihak di 9 desa di kecamatan Genteng yang diikuti oleh 6.720 orang. Demikian juga terjadi di Srono, Cluring, Kabat, Gambiran, Glagah, dan lain-lain. Panitia berharap pada Pantja Tunggal, atau pemerintah, agar dapat menghentikannya berdasarkan semangat Deklarasi Bogor (Antara, ibid.).

Kekuatan politik di tingkatan lokal Banyuwangi dan eskalasi aksi sepihak memberi pra-kondisi mobilisasi pembasmian PKI. Hingga pada gilirannya pembasmian itu lebih masif dan sistematis dengan datangnya pasukan Resimen Para Komando Angkatan Darat (RPKAD) di Banyuwangi, dan pembunuhan dilakukan "secara militer". Kontestasi politik di Banyuwangi meninggi dalam pemilihan bupati akhir tahun 1964. Terdapat empat kekuatan utama, tiga dari partai politik (PNI, NU dan PKI) dan satu kekuatan dari Militer PNI, dan Militer mengajak NU Blambangan mengusung calon Joko Supaat yang saat itu menjabat sebagai Komandan Distrik Militer Banyuwangi. Sedangkan NU cabang Banyuwangi berkoalisi dengan PKI mengusung Suwarso Kanapi. Koalisi ini bersifat dinamis, tidak ajeg sejak awal sebab diwarnai dengan kepentingan pribadi elit (Mustafa 2005). Demikian pula posisi militer. Pemilihan dimenangkan secara tipis oleh Suwarso Kanapi. Aksi penolakan terjadi di mana-mana, menuntut dibatalkannya pelantikan bupati. Delegasi besar dari Front Marhaenis yang dipimpin ketua PNI, Djakfar Makruf, dan umat Islam yang dipimpin ketua NU, Abdul Latif, berkumpul di pendopo kabupaten yang saat itu sedang berlangsung acara Musyawarah Komando Cacar $^{17}$. Mereka menyatakan ketidakpercayaannya pada bupati terpilih. Perpecahan semakin meruncing hingga ke desa-desa.

\section{Kekerasan hingga pembunuhan}

Ketegangan pra-1965 cukup terasa di Banyuwangi. Meski demikian tidak sampai terjadi perkelahian fisik atau bahkan pembunuhan, bahkan ketika terjadi aksi-aksi sepihak. Misalnya apa yang terjadi pada awal 1965 ini.

\section{Aksi penumpasan}

Peristiwa 30 September 1965 menjadi dalih penumpasan PKI dan mereka yang di-PKI-kan, dan pembunuhan massal yang terjadi di Indonesia. Perintah penumpasan oleh Panglima Kostrad Soeharto disampaikan pada 16 Oktober 1965. Di bawah komando Sarwo Edhie, mulai dari Jawa Tengah menuju Jawa Timur dan Bali, paramiliter yang dipesan bergerak melakukan pembasmian PKI dalam waktu tiga bulan sampai dengan Januari 1966. Mereka dilatih, dipersenjatai dan dijanjikan imunitas (Jenkins \& Kammen 2012). Banyuwangi adalah salah satu daerah di Jawa Timur yang paling parah terjadi pembantaian.

17. Saat itu berlangsung pemberantasan penyakit cacar (smallpox) di Banyuwangi (Suara Indonesia, 1965). 
Daerah lain adalah Kediri, Pasuruan / Probolinggo dan Situbondo (Cribb 2003: 50). Di wilayah Besuki ini aksi penumpasan dilakukan oleh sipil yang diorganisir militer dan dipimpin langsung Komandan Resort Militer Kolonel Sumadhi dan Komandan Distrik Militer Kolonel Joko Supaat. Kekuatan pasukan berasal dari Batalion 515 dan Artileri Medan (Armed) dari Malang. Basis pertahanan militer ada di kecamatan Tegaldlimo, Bangoredjo, dan Pesanggaran, dan untuk kota ada di Temanggungan, Kampung Melayu dan Kampung Mandar. Di Rogojampi penculikan dan pembunuhan dilakukan oleh kelompok agama. Selain penumpasan, aksi yang dilakukan adalah mempersiapkan perubahan radikal kebijakan dan kepemimpinan negara yang bekerjasama dengan TNI. ${ }^{18}$ Penumpasan ini di luar kendali pimpinan negara.

Komisi Pencari Fakta yang diperintahkan oleh Presiden Soekarno dalam laporannya tanggal 27 Desember 1965 menyebutkan bahwa ada sekitar 2.000 orang dibunuh di Banyuwangi. Oei Tjoe Tat sebagai anggota Tim menjelaskan

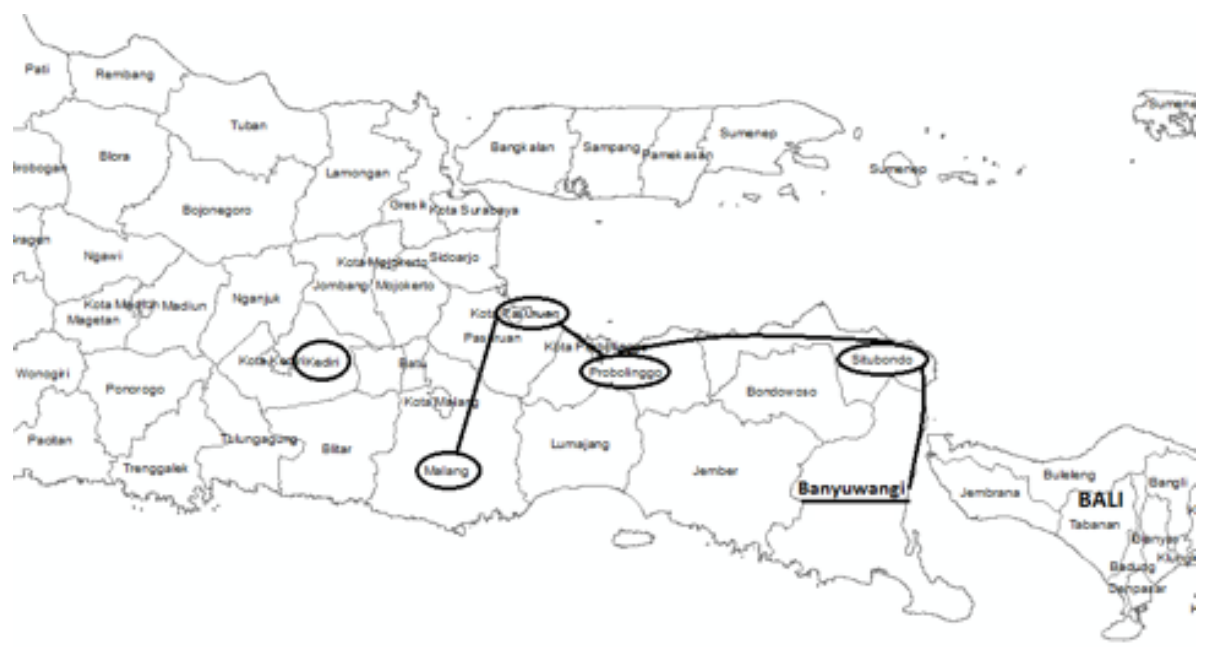

Gambar 1 - Terjadinya pembunuhan parah di beberapa kabupaten di ujung timur Jawa Timur (disebut wilayah Besuki)

ini dalam memoarnya (Oei Tjoe Tat 1995). Harould Crouch (1978), yang melakukan penelitian selang lima tahun setelah kejadian, mencatat:

\begin{abstract}
"On the eighteenth [Oktober] a large clash between PKI supporters and youths from Ansor, supported by the PNI's Pemuda Marhaen, occured in South Banyuwangi on the eastern tip of Java. Some thirty-five corpses were discovered on the eighteenth and another sixty-two in mass grave a few days later. During the next few days a massacre broke out in which several thousands PKI supporters lost their lives in the South Banyuwangi area and, as the news of killings spread, Muslim leaders in other part of East Java, usually with the tacit or express support of local military officers, prepared for onslaught against the PKI that was
\end{abstract}

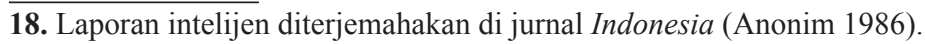


to last for several months." (Crouch 2007: 147)

Kejadian yang paling terkenal di Banyuwangi adalah "Peristiwa Cemethuk" Karangasem, Kecamatan Gambiran, wilayah tengah Banyuwangi. Report form East Java sebagai catatan intelijen tidak lama setelah kejadian menyebutkan bahwa kejadian Cemethuk ini dilakukan oleh para pemuda tanpa kalkulasi matang, "[...] and it is an experimental village". Dengan semangat yang menyala-nyala dan tanpa kalkulasi, kelompok pemuda dari Muncar dan Banyuwangi menaiki 4 truk, 3 mobil dan 4 motor, akan melakukan penyerangan menuju Desa Cemethuk. Penduduk Cemethuk yang mendengar akan adanya penyerangan dari Muncar dan Banyuwangi bersiaga. Mereka berbagi peran melumpuhkan para penyerang. Tatkala kendaraan masuk desa, pohon-pohon ditumbangkan penduduk. Penyerang terkunci dan mudah dilumpuhkan. Pertempuran terjadi. Korban berjatuhan di pihak para pemuda Ansor (organisasi pemuda dari Nahdlatul Ulama) dari Muncar/Banyuwangi tersebut. Penduduk memasukkan 62 mayat mereka ke dalam lobang-lobang yang digali kemudian.

Pada era berikutnya, narasi terhadap peristiwa dan keberadaan lobanglobang penguburan di Desa Cemethuk ini kemudian dikonstruksi sebangun dengan narasi "monumen lubang buaya" di Jakarta. Narasi ini tentu saja adalah replikasi dari narasi besar rezim. ${ }^{19}$ Narasi pasca-Soeharto saat ini menempatkan Peristiwa Cemethuk sebagai situs bertahannya penduduk terhadap serangan brutal dari luar (Purnama 2012; Krisnadi 2007: 1-13). Terlepas dari perdebatan historiografis ini, peristiwa Cemethuk menunjukkan bahwa sebelum kedatangan RPKAD yang melakukan operasi militer, perlawanan anggota PKI terjadi di Banyuwangi.

"Begitu djuga halnja kedjadian di Banjuwangi Selatan jang dimulai oleh pembunuhan terhadap 62 pemuda NAS-A (nasionalis dan agamis) dari Muntjar oleh PKI di Tjemetuk, sehingga mengakibatkan beribu2 korban dalam waktu jang singkat, semua ini tidak sadja merupakan permulaan dari tindakan2 pembalasan jang merata terhadap PKI dan ormasnja." (Oei Tjoe Tat 1995: 364)

RPKAD pada tanggal 20 Oktober 1965 menyisir daerah yang menjadi basis PKI seperti Desa Karangsem, Desa Lateng dan Desa Temenggungan. Bersama militer dilibatkan gabungan milisi yang memiliki keahlian bela diri, dikenal sebagai pasukan "Gagak Hitam”. Milisi ini sering diasosiasikan dengan kalangan Nahdlatul Ulama, di antaranya disebabkan oleh persaingan dalam pemilihan bupati Banyuwangi (Ikaningtyas 2015). ${ }^{20}$

19. Masih dijadikan tujuan kunjungan (merdeka.com 2016).

20. Kekerasan 1965 di Banyuwangi terhadap unsur yang dituduh PKI (dengan stigma ateis) yang dilakukan oleh masyarakat dan organisasi Islam, berakibat pada "peng-agama-an" pada periode-periode setelahnya. Para korban tidak memilih agama Islam yang dinilai telah menyakiti mereka, namun pilihan jatuh pada agama Hindu, seperti yang terjadi di Desa Kaligonde, Kecamatan Genteng (Galih Widhi Atma 2012). Bukan hanya PKI yang dituduh 


\section{Angka korban}

Soal angka sulit dipastikan. Bukan hanya karena besaran angkanya namun makna di balik angka-angka itu. Komisi Pencari Fakta menyebut angka 2.000 orang dibunuh. Angka ini kemungkinan bertambah sebab pendataan dilakukan hanya sampai bulan Desember 1965, dan Tim mengakui bahwa angka yang dilaporkan pejabat lokal itu terlalu kecil karena sengaja ditutuptutupi. Saat penyelidikan pembunuhan juga masih terjadi. Jika ditelusuri dari awal, korban-korban itu diperoleh dari hasil pendataan korban yang ditahan di kepolisian dan markas tentara. Saya sajikan pergerakan angka-angka itu.

Guna membuat penumpasan terstruktur dibentuk Badan Koordinasi Komando Siaga (BKKS). Badan ini kemudian bertransformasi menjadi Badan Komando Siaga (BKS) yang dibentuk di setiap desa dengan koordinator pihak militer. Melalui struktur ini pendataan terpantau dan penumpasan lebih massif (Purnama 2012: X). Operasi militer selama sebulan (pertengahan OktoberNovember) menangkap tahanan politik (tapol) PKI dari desa-desa. Mereka diangkut dan ditahan di Komando Resort Kepolisian 1037 Banyuwangi dan di rumah tahanan Polisi Militer (PoM) Pos Banyuwangi (18 Oktober hingga 17 November 1965). Jumlah tahanan sebanyak 254 orang. Sejumlah 58 orang dikirim ke Kalibaru, Jember dan Malang; 156 orang tahanan tetap di Komando Resort Kepolisian 1037 Banyuwangi; dan 40 orang di rumah tahanan POM Pos Banyuwangi. Laporan yang sama oleh Biro Tahanan di Banyuwangi menyatakan bahwa "seluruh tahanan G.30.S. jang tertjatat 257 nomor/orang, dari mereka ${ }^{2}$ jang didapat hasil operasi ${ }^{2} /$ menyerahkan diri/ melindungkan diri." Koordinator intel memberi catatan terhadap laporan ini agar diidentifikasi tahanan yang terlibat dalam Peristiwa Cemetuk Karangasem yang disebut sebagai kriminal politik, dan mana saja yang sebagai tahanan politik. ${ }^{21}$

Laporan bulan Juli 1966 menyebutkan bahwa setelah dilakukan pemeriksaan, maka para tahanan tersebut dimasukkan ke dalam beberapa golongan, yakni 47 orang dalam golongan A, 61 orang golongan $\mathrm{B}$, dan 53 orang dalam golongan $\mathrm{C}^{22}$. Sisanya tidak dijelaskan apakah telah dilepas

ateis, kelompok abangan juga. Pembunuhan juga terjadi pada tokoh agama Budha-Visnu di kaki gunung dan Kejawen di Puncak Tengger. Ekologi pegunungan dan politik-aliran memberi konteks pada pertarungan kelas dan kekerasan di wilayah ini (Hefner 1999: bab VII). Untuk tahu lebih lanjut tentang gejala konversi agama pasca-1965, lihat Nugroho 2008; Nugroho 2009; Shohibuddin dan Luthfi 2010: bab IV.

21. Dua laporan (24 halaman) Kepala Biro Tahanan Pelaksana Pupepelrada 083/0825 kepada Kepala Staf Pelaksana Pupepelrada 083/0825, tanggal 17 November 1965, Arsip EHO.

22. Secara resmi penggolongan yang sudah berjalan ini baru disahkan melalui Keputusan Komando Operasi Pemulihan Keamanan dan Ketertiban (Kopkamtib) No. Kep-028/ KOPKAM/10/68, yang mulai berlaku mundur sejak tanggal 18 Oktober 1968. Golongan A adalah mereka yang terlibat langsung, golongan B adalah mereka yang tidak terlibat langsung, dan $\mathrm{C}$ adalah orang-orang yang terindikasi, atau yang masuk akal kalau dianggap secara langsung atau tidak terlibat. Tindakan terhadap masing-masing golongan ini berbeda-beda. Lampiran tentang Keputusan Kopkamtib yang mengatur penggolongan ini, lihat Klinken (ed.) 
atau entah bagaimana. Para tahanan dikirim dari tahanan untuk dieksekusi, misalnya di kawasan hutan Cemoro Sewu dan di Jurang Baluran (Ikaningtyas 2015; Mustafa 2015). ${ }^{23}$

Laporan Komando Militer Banyuwangi kepada Komando Resort Militer di Malang tertanggal 20 Agustus 1966 menyajikan data bahwa anggota PKI di Banyuwangi kondisinya adalah: 6.008 orang (mati) ${ }^{24}, 1.040$ orang (wajib lapor), 115 (ditahan), 49 orang (melarikan diri).

Pada periode berikutnya semua kecamatan masih melakukan pendataan, seperti dilaporkan dari Kecamatan Gambiran, yang merupakan salah satu kecamatan dengan pengikut PKI terbanyak. Laporan militer mengenai kecamatan tersebut, tertanggal 2 Juli 1968, mencatat keseluruhan 2.259 orang yang dinyatakan sebagai anggota PKI dalam kategori F (simpatisan), hampir keseluruhannya adalah penduduk biasa, terbanyak adalah petani, tukang dokar, atau pedagang kecil simpatisan BTI, Gerwani, Sobsi, Lekra, Sobsi atau Pemuda Rakyat. Dijelaskan bahwa keseluruhannya sudah dikenai tindakan "wajib lapor" dan di lembar laporan ada kolom "processing/ tindakan selanjutnya" yang masih kosong (2 Juli 1968). Ini merupakan laporan paling lengkap dan tebal dalam mendaftar semua 2.259 nama pengikut PKI di kecamatan Gambiran. ${ }^{25}$

Pendataan berikutnya mencatat jumlah keseluruhan penduduk Banyuwangi di semua kecamatan yang dituduh terlibat G30S, namun tidak termasuk 86 orang yang belum tertangkap. Inilah angka yang bisa kita anggap final: 50.727 orang yang dianggap anggota PKI di Banyuwangi.

2017: 336-339.

23. Untuk lebih detil lihat "Laporan Pasi I, Komando Distrik Militer 0825, Pelda Djoemangat, pada Rapat Seksi I Korem 083 di Pasuruan", 14 Juli 1966, Arsip EHO.

24. Laporan Komando Militer Banyuwangi kepada Komando Resort Militer di Malang tertanggal 20 Agustus 1966. Dari sekian dokumen yang disimpan dalam Arsip EHO, menurut saya, angka kematian sejumlah 6.008 ini adalah angka terbesar yang dicatat dan dilaporkan otoritas resmi militer.

25. Laporan satu bundel ( 71 halaman) dari Komandan Korem 0825 Kecamatan Gambiran tentang "Rekapitulasi Anggota PKI jang Masuk Daftar 'F' Ketjamatan Gambiran”, 2 Juli 1968, Arsip EHO. 
Tabel 2 - Penduduk Banyuwangi yang Dituduh Terlibat G30S

\begin{tabular}{|c|c|c|c|}
\hline No & Kecamatan & Jumlah Tahanan & Pemilih PKI Pemilu 1955 $^{5}$ \\
\hline & Kota & 3.454 & 9.743 \\
\hline & Giri & 1.262 & 8.850 \\
\hline & Glagah & 3.668 & 7.432 \\
\hline & Genteng & 4.122 & 16.631 \\
\hline & Kalibaru & 1.685 & 10.636 \\
\hline & Gambiran & 2.519 & 13.390 \\
\hline & Cluring & 5.379 & 15.499 \\
\hline & Srono & 1.626 & 16.155 \\
\hline & Tegaldlimo & 1.722 & 18.378 \\
\hline & Bangorejo & 1.344 & 12.343 \\
\hline & Pesanggaran & 2.631 & 19.134 \\
\hline & Rogojampi & 2.366 & 6.636 \\
\hline & Singojuruh & 5.265 & 12.989 \\
\hline & Klabat & 2.643 & 4.433 \\
\hline & Wongsorejo & 1.062 & $?$ \\
\hline & Glenmore & 2.904 & $?$ \\
\hline & Muncar & 1.443 & 172.249 \\
\hline & Purwoharjo & 5.632 & 50.727 \\
\hline
\end{tabular}

Dari data di atas tampak bahwa penduduk yang dituduh terlibat G30S cukup banyak di Kecamatan Purwoharjo, Cluring, Genteng, Gambiran, Srono, Tegaldlimo, Bangorejo, Pesanggaran, yang mayoritas adalah pedesaan di wilayah Banyuwangi Selatan. Di tempat itu memang pemilih PKI pada Pemilu 1955 cukup menonjol. PKI memperoleh suara tertinggi di Banyuwangi 172.249 (43,22\%), disusul NU 150.927 (38,43\%) dan PNI 75.071 (18,35\%).

Ringkasnya, terdapat 6.008 orang mati dibunuh di Banyuwangi berdasarkan Laporan militer tertanggal 20 Agustus 1966, dan 50.727 orang ditahan berdasarkan Laporan militer tertanggal 2 Juli 1968.

\section{Kekerasan Politik}

Perkembangan situasi keamanan dan politik tidak lama setelah peristiwa G30S memang mencekam. Terjadi kekerasan politik berupa pembersihan politis (bisa berujung pada penghilangan nyawa) di pelbagai jawatan pemerintah, lembaga pendidikan, dan organisasi politik.

Beberapa hari sesudah pembunuhan para jenderal, semua pihak di Banyuwangi berjaga-jaga terhadap segala kemungkinan. Rumor berkembang di mana-mana. Sebagai contoh, sebuah laporan rahasia Puterpra ${ }^{26}$ menyebutkan

26. Laporan rahasia Puterpra Bagoredjo kepada Dandim 0825 Banyuwangi, tanggal 8-10- 
bahwa anggota-anggota Pemuda Rakyat akan menculik 6 pemuda Ansor dan NU dari Ringintelu. ${ }^{27}$ Laporan ini juga menyatakan bahwa seorang camat, yang kemungkinan PKI, didatangi oleh tamu berkendaraan mobil pick-up yang membawa dua peti yang ditengarai berisi senjata api. Selain itu tercatat juga bahwa orang yang sama telah memesan pedang ke pandai besi di Kebondalem. Bahkan dikatakan bahwa Bangoredjo telah kemasukan 40 atau bahkan 75 pucuk senjata api dari orang-orang komunis. Juga disiapkan dapur umum dalam kegiatan mereka ini dan Pemuda Rakyat menyiapkan lada yang ditumbuk dan dicampur dengan gamping dan sebagai semprotannya mereka membuatnya dari bambu. Laporan ini mengatakan bahwa "Persiapan ini akan digunakan dan ditudjukan kepada para pendjabat2 2 penting dan terutama Angkatan Bersendjata."

Pergerakan pengikut PKI langsung diawasi. Laporan tersebut di atas mencatat bahwa pada bulan Oktober, dua orang yang dianggap sebagai gembong komunis pindah dari Kota Banyuwangi ke Kalipait Tegaldlimo dengan diantar 6 truck. Pihak militer menaruh curiga dan meyakini bahwa mereka sedang menyusun kekuatan di tempat lain. Mereka juga mengadakan rapat gelap di hutan Baruredjo dan di Desa Baluredjo. Laporan ini ditutup dengan usulan agar kekuatan militer di wilayah ini ditambah personil dan logistik-persenjataan.

Dalam satu laporan Puterpra dari kecamatan yang lain, yakni Kecamatan Pesanggaran, tercatat jumlah orang mati sebanyak 111 jiwa dalam tempo 10 hari (10-20 Desember 1965). Hampir keseluruhan mereka yang mati ini adalah petani dengan keterangan afiliasi ormas BTI, 4 orang bekerja sebagai pegawai Perhutani, 1 orang pegawai kecamatan, 3 sebagai guru SD dengan afiliasi ormas-nya adalah Gerwani, Pemuda Rakyat, atau PKI dalam status aktif, atau jika tidak, disebut sebagai bromocorah. ${ }^{28}$

Bukan hanya terhadap warga sipil, pembunuhan juga terjadi pada anggota tentara/aparat keamanan yang dituduh sebagai pengikut/simpatisan PKI. Sekitar 12 orang dari kecamatan yang berbeda, yang tercatat sebagai

1965, Arsip EHO. Puterpra/Buterpra adalah akronim dari Perwira/Bintara Urusan Teritorial dan Perlawanan Rakyat, istilah teritorial militer di tingkat kecamatan. Pada tahun 1950an disebut Bintara Onder Distrik Militer. Teritori militer ini sekarang dikenal dengan Koramil, Komando Rayon Militer.

27. Telah cukup dikaji bahwa laporan yang beredar dari sumber militer perlu diperlakukan secara skeptis. Kajian Robinson (1995, 2006), hingga laporan IPT 65 (Klinken 2017) menunjukkan bahwa terdapat keterlibatan pihak asing (CIA) di dalam menyuplai logistik aksi penumpasan, termasuk dokumen nama-nama target dan aksi propaganda penumpasannya. Selain Amerika, keterlibatan asing lain adalah Inggris dan Australia.

28. Daftar yang disusun oleh Asisten Wedana Pesanggaran, "Daftar Adanja Orang2 Jang Meninggal Dunia Akibat Terlibat G.30.S dalam Daerah Ketjamatan Pesanggaran, mulai tanggal 10 s/d 20 Desember 1965”, tanggal 15 (sic.) Desember 1965, Arsip EHO. 
anggota PNI (1 orang), NU ( 8 orang), dan Muhammadiyah (3 orang), dituduh melakukan "pembunuhan liar" terhadap 4 personil tentara. ${ }^{29}$

Secara rinci terdapat daftar nama-nama anggota PKI. Sejak dibentuk BKS di desa-desa, kontrol atas pergerakan anggota PKI semakin kuat. Terdapat juga catatan daftar koordinator-koordinator PKI di tingkat wilayah. Mereka ini menjadi target utama penumpasan. ${ }^{30}$

Ceceran catatan kecil seperti ini menopang bangunan besar mengenai aksi penculikan yang berlangsung terencana. "Sendjata Revolver Colt Cobra No. 38094, 12 [dua belas] butir peluru [...] diamankan di kantor Perhutani Bwi Slt." Terdapat seorang anggota Front Nasional yang sekaligus merangkap anggota Hansip meminjam revolver tersebut dari orang lain. Senjata ini digunakan untuk menculik seseorang. Dalam catatan tulis tangan itu pemilik senjata membuat surat pengakuan bahwa ia telah meminjamkan kepada orang pertama. ${ }^{31}$ Senjata itu kemudian diambil oleh aparat atas perintah seorang Letda., lalu "disimpan dulu menunggu perkembangan baru". ${ }^{32}$

Di lembaga pendidikan, seorang guru Sekolah Pendidikan Guru Negeri Banyuwangi yang mengajar pelajaran Sejarah dan Civic diskors oleh kepala sekolahnya. Ia diindikasi 'terlibat'. Kasus ini menyita perhatian publik pendidikan di Banyuwangi. Berbagai pihak memberi dukungan dan pernyataan bahwa yang bersangkutan bukan anggota PKI. Demikian pula pernyataan protes dari murid SPGN Banyuwangi yang menyatakan bahwa justru mereka "bersjukur digembleng dan dididik oleh $[\ldots]$, sehingga $[\ldots]$ [m]emperoleh petunjuk terang dalam kita menudju Masjarakat Sosialis Indonesia jang berdasarkan Pantja Sila." Tim delegasi atas nama masyarakat Banyuwangi juga memberi kesaksian serupa. Seorang pengurus Ancab PNI memberi pernyataan bahwa orang tersebut adalah anggota PNI. Tuntutan berbagai elemen itu serupa yakni agar pihak berwenang mencabut skorsingnya dan menuntut agar Kepala Sekolah SPGN Banyuwangi ditindak karena melakukan "penjalahgunaan wewenang", dan "pembontjengan terhadap Peristiwa Gestok". Maka dibentuk tim screening untuk membuktikan tuduhan itu. Tuntutan-tuntutan ini marak pada bulan Juli $1966^{33}$.

Para pejabat pemerintah yang dituduh anggota PKI tidak luput dari aksi penumpasan di Banyuwangi. Surat yang mengatasnamakan "Rakjat DATI II Banjuwangi" tertanggal 11-11-1965 ditujukan kepada seorang Pelaksana

29. Arsip EHO, tulisan tangan tanpa tanggal.

30. "Turunan daftar coordinator Dosen dan Petugas CSS PKI Rogodjampi", tanpa tanggal, Arsip EHO.

31. "Surat pengakuan", 9 Desember 1965, Arsip EHO.

32. "Surat disposisi seorang letnan dua", 11 Desember 1965, Arsip EHO.

33. Laporan seorang guru kepada Komandan Pelaksana Pupepelrada Dati II Banyuwangi, dengan lampiran bukti-bukti berbagai dukungan terhadap rekan guru yang dituduh PKI, 4 Juli 1966, Arsip EHO. 
Pupepelrada Banyuwangi, menuntut agar militer segera mengambil tindakan terhadap seorang pegawai Lembaga Permasyarakatan Banyuwangi yang dituduh sering berhubungan dengan tokoh PKI Banyuwangi. Seorang pegawai P.D.K. Banyuwangi dituduh sering melakukan rapat gelap PKI di rumahnya dan melindungi pelarian G30S, serta guru-guru PKI lainnya. Seorang pegawai Kantor Pendaftaran Tanah Banyuwangi dituduh sering melakukan "dalam memberikan sertipikat hak milik tanah selalu memberikan prioritas pada orang-2 P.K.I. dan memberikan segala rahasia pelaksanaan LANDREFORM KEPADA orang-2 P.K.I. sehingga orang-2 P.K.I. mempunjai bahan jang kuat dalam melaksanakan AKSI SEPIHAK DULU". Seorang pegawai Kantor Pajak Banyuwangi dituduh terlalu membela PKI dalam pengampunan pajak, berkolusi dengan masyarakat Tionghoa sehingga bisa memupuk kekayaannya ${ }^{34}$. Berbagai pihak di instansi pemerintah tidak luput dari aksi kekerasan politik ini, termasuk di kepemimpinan sipil.

Militer segera mengambil-alih posisi kepemimpinan masyarakat. Terdapat 42 kepala desa yang dinyatakan sebagai PKI dan harus diganti. Surat Keputusan Komandan Pelaksana Pupepelrada tertanggal 1 Maret 1966, menunjuk 35 orang pengganti yang berasal dari militer/polisi dan 7 orang dari sipil ${ }^{35}$. Dengan diangkatnya mereka ini maka wakil kepala desa yang sebelumnya memimpin desa secara transisional dikembalikan pada posisinya semula. Ini menjadi sinyalemen yang menunjukkan "efektivitas pengawasan" terhadap penduduk desa. Desa menjadi "rumah kaca" bagi rezim yang baru naik.

Pembunuhan dan pengusiran berakibat banyaknya barang-barang milik anggota PKI terlantar. Barang-barang itu kemudian 'diamankan' oleh militer, misalnya seperangkat gamelan, sangkakala dan alat drumband milik organisasi PKI, radio-aki dan sepeda motor rusak milik bekas kepala desa, radio transistor, sepeda kayuh, lampu tingkwan, dll. Kesemuanya dibawa ke Puterpra. ${ }^{36}$ Juga terjadi pembakaran rumah-rumah, di antaranya di Kecamatan Kabat. Dalam waktu tiga hari (16-18 Oktober 1965) terjadi perusakan terhadap 113 rumah serta pembakaran 222 rumah beratap genteng dan walit ${ }^{37}$.

Akhir tahun 1966 situasi masih mencekam. Masing-masing kelompok membekali diri dengan ilmu kesaktian dan persenjataan. Kelompok agama sering mengadakan pengajian di desa-desa disertai pengisian 'asmak' yakni memasukkan kekuatan dan kesaktian ke dalam benda-benda seperti ikat kepala, cemeti, senjata tajam, tongkat, dan lain-lain. Sementara itu kelompok

34. Surat yang mengatasnamakan "Rakjat DATI II Banjuwangi" tertanggal 11-11-1965 ditujukan kepada seorang Pelaksana Pupepelrada Banyuwangi, Arsip EHO.

35. Surat Keputusan Komandan Pelaksana Pupepelrada tertanggal 1 Maret 1966, Arsip EHO.

36. "Laporan anggota Puterpra", 23 Maret 1966, Arsip EHO.

37. Laporan petugas Urusan Teritorial \& Perlawanan Rakyat 0825/IX kepada Komandan Distrik Militer 0825/Koordinator I, Banyuwangi, "Daftar adanja barang2 milik orang2 jg tersangkut G.30.S”, tanggal 21 Maret 1966, Arsip EHO. 
nasionalis yang sering dicap abangan juga melakukan hal serupa. Mereka pergi berguru ke seorang perempuan di Ngawi, wilayah perbatasan dengan Jawa Tengah, untuk mendapatkan kekebalan dan kesaktian. Bagi Distrik Militer tindakan-tindakan seperti itu dikhawatirkan akan mudah ditunggangi Gerakan Politik/PKI dalam memperkokoh kekuatannya, serta dinilai tidak sesuai dengan Pancasila yang menyatakan Ketuhanan Yang Maha Esa.

Dari sisi kondisi sosial, dilaporkan bahwa di dalam kota terdapat banyak gelandangan yang "dilihat dari wadjahnya dipastikan berasal dari luar", yang dikhawatirkan adalah pelarian anggota PKI. Fenomena gelandangan ini dinilai akan menyulitkan pendataan anggota PKI yang ada di Banyuwangi. Maka dilakukan pencatatan nama-nama mereka. Banyak yang ketakutan sehingga pergi atau berpindah tempat masih di wilayah Banyuwangi ${ }^{38}$.

Bahkan pelecehan masih terjadi seperti terhadap perempuan-perempuan yang dituduh Gerwani, dari yang mulai berumur 13 tahun hingga 30 tahun. Mereka digunduli atas perintah komandan peleton pertahanan sipil (danton Hansip). Selain adanya pasukan tempur yang diorganisir itu, terdapat catatan nama algojo untuk wilayah pembunuhan tertentu ${ }^{39}$.

Sampai dengan tahun 1968 pembunuhan masih terjadi. Berbeda dengan aksi penumpasan yang dipimpin oleh militer sampai dengan bulan Februari 1966 dan pengiriman tahanan oleh militer untuk dibunuh sipil, pada bulanbulan berikutnya, pembunuhan dilakukan oleh sipil dengan bantuan dari aparat militer, atau setidak-tidaknya diketahui dan disetujui oleh mereka. Dalam satu periode terdapat orang mati secara massal.

Sebuah catatan Puterpra tingkat kecamatan tertanggal 5 Juli 1968 menyebutkan bahwa jumlah eks-PKI se-kecamatan sebanyak 5.379 orang. Jumlah orang yang meninggal 110 jiwa, dan yang dinyatakan hilang 196 jiwa. Daftar dari satu kecamatan lain menyajikan data 124 orang mati dalam waktu kurang dari 2 bulan (hanya bulan Oktober-Desember 1965). Kebanyakan adalah petani $\mathrm{BTI}^{40}$.

\section{Dokumen dan keterlibatan militer}

Dalam dokumen militer yang disajikan di atas tidak ditemukan secara langsung aksi-aksi penumpasan yang dilakukan oleh militer. Tentara sebagai penyusun informasi dalam dokumen itu bersifat mencatat atau melaporkan, mengambil posisi layaknya sebagai saksi, pengumpul informasi melalui kerja-kerja rutin atau intelijen, atau setidaknya mendapat laporan dari pihak luar. Dengan kata lain, membaca dokumen ini, lahir kesan militer bersikap pasif atas apa yang terjadi dalam peristiwa dan kekerasan di Banyuwangi.

38. Laporan Kepala Staf Komandan Distrik Militer 0825, "Laporan Singkat Situasi Terachir KODIM 0825/Banjuwangi”, 22 September 1966, Arsip EHO.

39. Laporan Situasi Daerah Puterpra 0825/IX Tegaldlimo, 7 Maret 1966, Arsip EHO.

40. Daftar yang disusun oleh Komandan Kodim 0825/7, Kecamatan Cluring, "Rekapitulasi ExPKI dalam Ketjamatan Tjluring”, 5-7-1968, Arsip EHO. 
Laporan yang mencerminkan tindakan aktif dilakukan militer adalah melakukan pencegahan, penangkalan atas tindakan bentrok yang terjadi, pengadministrasian mengenai jumlah tahanan, dan pelaporan-pelaporan lain pada otoritas yang lebih tinggi.

Ada satu dokumen yang secara samarmengatakan demikian, "Setelah G.30.S selesai dikerdjakan dalam arti kata militer [penekanan ditambahkan], maka keadaan politik terutama suasana kepartaijan kelihatan adanja bentrokan." ${ }^{41}$ Pendukung partai curiga dan waspada satu dengan lainnya. Selain pada penekanan "dalam arti kata militer" pada kalimat di atas, sesuatu yang makin menjadi (di)kabur(kan) adalah karena kalimat itu tidak menyebutkan tindakan apa yang "dikerdjakan" itu. Kalimat laporan ini tidak memasukkan kata misalnya, "Setelah pembersihan/pembasmian/pembunuhan/ G.30.S selesai". Jika menempatkannya pada konteks yang lebih luas, kita bisa memperhatikan hal-hal berikut. Seperti dijelaskan di depan bahwa penumpasan PKI di bawah komando Sarwo Edhie dimulai dari Jawa Tengah menuju Jawa Timur dan Bali terjadi pada pertengahan Oktober 1965 hingga Januari 1966. Jika melihat tanggal laporan yang dirujuk di atas, 1 Februari 1966, maka frase "dalam arti kata militer" itu ada dalam konteks aksi penumpasan tiga bulan tersebut.

Catatan situasi riil di semua kecamatan yang diperintahkan oleh PASI I Kodim 0825 Banyuwangi agar dilaporkan oleh para bawahan militer di koramil, adalah bahan yang sangat berharga yang harus diungkap secara hati-hati. Dari catatan ini keterlibatan militer dalam penghilangan massal di Banyuwangi terkuak. Memang tidak mudah ditemukan dokumen yang secara eksplisit menyatakan itu. Sebagaimana dalil bahwa pembunuhan yang dilakukan oleh rezim secara resmi tidak mungkin dicatat. Meski demikian masyarakat tahu belaka keterlibatan mereka, seperti yang disebut John Roosa (2016), "pengetahuan tentang sebuah rahasia umum".

Dalam laporan situasi dari satu kecamatan pasca pembasmian menyeluruh di Banyuwangi (tertanggal 7 Maret 1966), catatan pertama berbunyi, "Sesudah penumpasan G30S, keadaan umumnja baik. Tetapi kenjataannya masih ada disana-sini terdapat suara-suara dari seseorang jang sipatnja menakut-nakuti/ antjaman-antjaman terhadap orang lain jang mengakibatkan paniknja orang-2 jang mendjadi sasaran." ${ }^{\prime 2}$ Dokumen ini ingin mengatakan bahwa penumpasan oleh militer terhadap PKI sudah selesai dilakukan, namun ternyata masih terjadi kekerasan-kekerasan yang dilakukan oleh sipil, yakni mereka yang digolongkan sebagai unsur NASA terhadap unsur $\mathrm{KOM}^{43}$ : yang berperan sebagai 'slagorde' 44 adalah PNI dan NU.

41. "Laporan seorang anggota Puterpra tentang Situasi Daerah Kalibaru Mengenai Politik/ Keamanan", 1 Februari 1966, Arsip EHO.

42. Laporan Situasi Daerah Puterpra 0825/IX Tegaldlimo, tanggal 7 Maret 1966, Arsip EHO.

43. NASAKOM adalah akronim dari NASionalis, Agama, KOMunis. Penggambaran atas tiga kelompok besar ideologi-politik yang dianut saat itu.

44. Istilah asli bahasa Belanda yang digunakan dalam dokumen, artinya adalah pasukan tempur.

Archipel 95, Paris, 2018 


\section{Pengusiran, perampasan tanah dan pembelaannya}

Tindakan perampasan tanah dan depopulisasi (pemusnahan orang) menjadi bagian yang tidak terpisahkan dari penciptaan teror terhadap masyarakat. Perampasan tanah dari penerima atau calon penerima Land reform, dilakukan oleh pemilik lama, petualang, pejabat desa, militer, perusahaan perkebunan, bahkan pemerintah daerah.

Kasus yang paling menonjol perampasan tanah adalah tanah bekas milik seseorang di suatu kecamatan di Banyuwangi. Sang pemilik tanah tinggal di Madura sehingga tanahnya dinyatakan sebagai tanah absentee/guntai. Akan tetapi aparat keamanan menyita tanah tersebut dengan alasan tanah itu bukan tanah obyek Land reform, karena telah dihibahkan kepada seorang lain melalui penggarap tanahnya atas perintah sang pemilik tanah pada tahun 1959. Berdasarkan musyawarah tersebut, mengatasnamakan anggota Panitia Land reform Gaja Baru kecamatan tersebut dalam surat pernyataan ini diputuskan penyitaan tanah itu. Pertanggungjawaban dan pengamanan hasilhasil penyitaan tanah diserahkan kepada Tritunggal. ${ }^{45}$

Tidak cukup dengan itu, yang unik lagi adalah ketentuan militer mengenai penerima hasil tanah yang disita tersebut. Dinyatakan bahwa selama dalam penyitaan hasil tanah itu dibagi 50\% untuk penggarap dan 50\% Daerah. Akibatnya petani yang telah menjadi pemilik melalui Land reform kembali menjadi penggarap. Pembagian untuk 'Daerah' ini maksudnya adalah 25\% untuk pembangunan kecamatan dan $25 \%$ untuk administrasi. Bagian $25 \%$ untuk administrasi ini dibagi rata lima pihak: administrasi kecamatan, Kepolisian Sektor, Kepolisian Distrik, Koramil, dan Agraria Kabupaten Banyuwangi.

Di satu kecamatan lain muncul perampokan dan pembunuhan menentang peraturan pemerintah mengenai pelaksanaan Land reform yang dilakukan oleh seorang kader NU, sekaligus bekas anggota Sarbupri (Sarekat Buruh Perkebunan Republik Indonesia). Bersama 19 anak buahnya, mereka melakukan pembunuhan dan perampokan liar di beberapa daerah lain. Ia bersama gerombolannya sering diminta bantuan, misalnya untuk melakukan pengambil-alihan kembali tanah hasil redistribusi Land reform. Kasus ini telah masuk ke Puterpra (laporan P.V.O. tertanggal 11 Januari 1966).

Pasca penumpasan PKI juga memunculkan para petualang. Contohnya seorang yang berusaha mencari pengaruh terutama dengan cara menekan masyarakat Tionghoa. Ia membangun mushola di atas bekas tanah milik orang yang dituduh sebagai anggota Pemuda Rakyat. Ia mengancam dan merusak rumah pengelola tanah tersebut agar keinginannya terpenuhi. Biaya pembangunan mushola diperoleh dari setoran masyarakat Tionghoa,

45. Tritunggal maksudnya adalah pemerintah, dalam doktrin kesatuan antara pemerintah dengan militer dan rakyat. 
sumbangan batu bata merah dari orang lain, pasir secara kerja bakti, dan tenaga kerja diperoleh dari orang-orang PNI (kiri) yang takut dengan petualang itu. ${ }^{46}$

Berlarut dan bahkan terhentinya proses redistribusimembericelah spekulasi. Terjadi perampasan tanah dan pencabutan tanaman oleh seorang kepala desa. Ia melakukan bersama pembantu-pembantunya. Tindakan ini buah dari kemelut proses peralihan atas tanah berhektar-hektar dalam 14 bidang. Tanah ini sebenarnya masih dalam proses "sengketa", yakni diproses sebagai tanah obyek Land reform. Tetapi pemiliknya malah memanipulasinya dengan cara mewariskan kepada cucunya, seorang tentara. Belum sampai membuahkan hasil, kudeta 1965 membuat proses ini berhenti. Surat pernyataan penyerahan bidang sawah tersebut uniknya dibuat dan ditandatangani tertanggal 4 November 1966, mengindikasikan adanya tindakan memanfaatkan huru-hara politik G30S saat itu. Berbekal inilah kemudian orang tentara di atas mengirim surat kepada Komandan Sektor Kepolisian pada tanggal 17 November 1966 yang berisi tuntutan "pemeriksaan lebih landjut" kepada kepala desa tersebut, karena "merampas hak milik tanah sawah milik orang lain tanpa idjin"47. Dalam surat ini, kepala desa dkk. juga dituduhnya melakukan tindakan perusakan berupa menebang pohon kelapa dan mencabuti pohon ketela di atas tanah milik kakeknya tersebut. Persengketaan yang berlarut itu mengakibatkan tanah sawah menjadi bokor atau terlantar.

Aksi pengusiran dan pemerasan pada bulan Februari 1966 dilakukan oleh sekelompok terhadap orang yang dituduh sebagai PKI dan ditarik uang sebesar Rp 25.000-50.000 jika ingin tetap bisa tinggal di desa. Total uang yang diperoleh seorang dari ketigabelas orang ini adalah Rp. $430.000^{48}$.

Seorang Ulu-ulu (petugas pengairan) dalam beberapa hari secara terusmenerus melakukan teror terhadap sejumlah orang yang dikenal sebagai simpatisan BTI. Bukan hanya kepada mereka yang menerima dan meninggali tanah kering hasil redistribusi itu, namun dengan dalih "tersangkut peristiwa 65", pelaku tersebut merusak rumah orang atau memaksa membeli murah rumah mereka yang akan diusirnya. Tindakan ini akan dicegah Puterpa bukan sebab alasan kemanusiaan, namun karena "akan menyulitkan ABRI dalam mengawasi eks-PKI"49.

Elit Banyuwangi juga mengambil kesempatan ini untuk mendapatkan tanah luas. Seorang kader PNI dan lawan politik dari PKI sejak Pemilu 1955, dikabarkan mampu mengakumulasi tanah hingga puluhan hektar. ${ }^{50}$ Unsur

\section{6. "Laporan Pos Kepolisian Muncar", 9 Juli 1966, Arsip EHO.}

47. Surat seorang Serda polisi kepada Komandan Sektor Kepolisian Kecamatan Singojuruh, perihal "Menuntut diri seorang Kepala Desa Songgon pribadi karena merampas hak milik tanah sawah milik orang lain tanpa idjin", 17 November 1966, Arsip EHO.

48. Surat, 22 Februari 1966, Arsip EHO.

49. Dokumen, 6 Maret 1966, Arsip EHO.

50. Wawancara dengan Suhalik, Giri, Banyuwangi, 6 Oktober 2016. 
lembaga negara juga ambil bagian. Terdapat contoh tanah absentee yang telah diputuskan oleh Panitia Land reform diambil alih oleh KKO (Korps Komando Operasi) Angkatan Laut. Bahkan tanah-tanah yang telah ditetapkan sebagai obyek Land reform dapat kembali pada pemiliknya semula melalui proses yang bersifat 'legal', artinya difasilitasi oleh negara (Kantor Pertanahan Banyuwangi, tanpa tahun A). Tujuan Land reform dari yang semula "tanah untuk penggarap" yang diambil dari tuan tanah/feodal atau bekas perkebunan (redistribusi), kini justru terbalik: tanah penggarap untuk perusahaan perkebunan. Terjadi pemusatan tanah pasca-1965 (rekonsentrasi). Nyata bahwa pengambil-alihan kembali tanah oleh berbagai pihak ini dilakukan dengan cara "making die" ataupun "letting die". Hasilnya diakumulasi oleh sipil/tokoh elit, militer, pejabat desa, dan yang tampak menonjol adalah oleh perusahaan perkebunan. Akumulasi terjadi melalui perampasan.

Tabel 4 - Perampasan Tanah pasca-65 oleh berbagai pihak. Sumber: Diolah dari berbagai dokumen yang dikelola oleh Etnohistori (Arsip EHO)

\begin{tabular}{|l|l|l|l|}
\hline Sipil & Militer & $\begin{array}{l}\text { Pamong desa/ } \\
\text { pejabat }\end{array}$ & Perusahaan \\
\hline $\begin{array}{l}\text { Pengambil-alihan } \\
\text { oleh pemilik semula }\end{array}$ & $\begin{array}{l}\text { Perampasan tanah } \\
\text { dan penetapan secara } \\
\text { sepihak bagi hasil }\end{array}$ & $\begin{array}{l}\text { Perampasan tanah } \\
\text { oleh kepala desa }\end{array}$ & $\begin{array}{l}\text { Rekonsentrasi 4 } \\
\text { HGU: } \\
\text { HGU PT. Amali and } \\
\text { Family (SK Men- } \\
\text { dagri, HGU tanggal } \\
\text { 4-5-1973), } \\
\text { PT. Tawangalun } \\
\text { (SK Mendagri HGU }\end{array}$ \\
$\begin{array}{l}\text { Perampokan dan } \\
\text { pembunuhan serta pe- } \\
\text { nolakan Land reform; } \\
\text { perampasan tanah }\end{array}$ & Klaim sepihak & $\begin{array}{l}\text { Pengambil-alihan No. 73/ } \\
\text { tanah ladang dan } \\
\text { perusakan rumah } \\
\text { yang ditinggali petani } \\
\text { penggarap }\end{array}$ & $\begin{array}{l}\text { HGU/DA/1973, tang- } \\
\text { gal 20-10-1973) } \\
\text { PT Gunung Trisni, } \\
\text { PT. Bhaladika Jay } \\
\text { Mayoritas di Kalibaru }\end{array}$ \\
\hline $\begin{array}{l}\text { Pengusiran dan } \\
\text { pemerasan }\end{array}$ & $\begin{array}{l}\text { Tindakan KKO yang } \\
\text { mengakuisisi tanah } \\
\text { Land reform }\end{array}$ & mengakumulasi tanah & \\
\hline
\end{tabular}

Kebijakan nasional terhadap nasib tanah-tanah (dan orang penerima) redistribusi program Land reform diputuskan persis setelah aksi penumpasan militer berakhir. Menteri Agraria R. Hermanses SH. sebagai Ketua BP Panitia Land reform Pusat pada tanggal 17 Februari 1966 menginstruksikan kepada Panitia Land reform di seluruh Indonesia agar tanah hasil redistribusi yang ditinggalkan oleh penerimanya karena "epilog Gestapu"(yang artinya adalah mereka terbunuh melalui proses penumpasan militer/sipil tersebut), dikuasai oleh Panitia atas nama Menteri Agraria. Jika anak-istri korban masih ada maka hak garap ada pada mereka; jika tidak ada, maka bersifat sementara akan diberikan hak garapnya kepada petani lain. Hasil dari penggarapan ini 2/3 untuk penggarap dan 1/3 untuk Kas Desa (pembangunan desa dan yatim- 
piatu Gestok ${ }^{51}$ (Kompas 1966). Menarik bahwa di sini keturunan mereka yang dianggap terlibat PKI masih diakui hak atas tanahnya. Namun, ini pernyataan resmi pemerintah. Dalam praktiknya di lapangan tidaklah demikian.

Pengambil-alihan oleh pemilik lama, petualang atau saat itu diistilahkan dengan "bromocorah", militer, dan pemerintah daerah justru sering terjadi. Sulit bagi Panitia dalam kondisi semacam itu dituntut untuk menertibkan ulang pasca-1965. Belum lagi muncul banyak petualangan para pihak yang telah melakukan pengambil-alihan tersebut.

Sebaliknya, apa yang dilakukan pasca-1965 adalah melanjutkan pembagian tanah obyek Land reform bukan kepada penggarap yang tepat, namun justru pada pemilik semula (dalam kasus di atas adalah diberikan dalam bentuk HGU). Ini memformalisasi tanah yang diambil-alih oleh pihak baru yang bukan berhak, atau setidak-tidaknya melanjutkan program Land reform tanpa melibatkan unsur organisasi tani sehingga penerimanya adalah bukanlah mereka yang tepat dalam kategori kelas agraria yang seharusnya.

Bagaimana respon organisasi tani terhadap pengambil-alihan kembali tanah rakyat itu? Tidak banyak catatan yang ada. Jikapun ada sangat kecil dan terbatas perlawanannya, dengan resiko berbenturan dengan kondisi umum saat itu. Namun, menarik melihat bahwa memang bisa ada perlawan yang efisien pada saat itu, kemungkinan besar karena didukung oleh kondisi lokal dan para aktor dari organisasi petani yang tidak dianggap dekat dengan PKI. Apa yang dilakukan oleh Pertanu dan Petani dalam uraian ini menunjukkan bahwa mereka bukan pelaku counter-Land reform, tapi justru pembela capaian Land reform dari ancaman perampasan..$^{52}$

Di satu wilayah perkebunan terjadi pengusiran terhadap para petani. Melihat kondisi tersebut, Pertanu mengeluarkan surat protes kepada pihak perkebunan dan menuntut diberikannya pemberian perlindungan terhadap rakyat tani yang telah melakukan pendudukan di wilayah tersebut. Surat kader Pertanu berisi desakan agar pimpinan perkebunan membatalkan rencana "memperkebunkan kembali" tanah-tanah yang dimanfaatkan rakyat, menghentikan pembuatan lubang yang merusak tanaman rakyat, mengganti kerugiannya, serta kesediaan berunding antara pihak Perkebunan dengan Pertanu dan Sarbumusi (Sarekat Buruh Muslim Indonesia)..$^{53}$

51. Kompas 1966. Istilah Gestapu (Gerakan September Tiga Puluh) dan Gestok (Gerakan Satu Oktober) menunjukkan pandangan politik masing-masing penggunanya dalam menyebut gerakan yang dipimpin oleh Letkol. Untung Samsuri (Setiawan 2003). Dalam konteks narasi di atas, yatim-piatu Gestok artinya adalah anak-anak di pedesaan yang ditinggal mati bapakibunya sebagai dampak dari peristiwa G30S tersebut.

52. Diperlukan penelitian-penelitian lanjutan mengenai contoh sukses pembelaan dari ancaman counter-Land reform atau bahkan kajian mengenai keberhasilan Land reform itu sendiri di tingkatan kelembagaan maupun masyarakat tanpa ada konflik yang berarti. Luthfi (2017) secara khusus mendalami peran dan pembelaan Pertanian Nahdlatul Ulama ini terhadap penerima redistribusi tanah dalam kebijakan Land reform.

53. "Surat Pertanu Banyuwangi tanggal 23 Juni 1966”, Arsip EHO. 
Pada kondisi sebelumnya rakyat tani yang miskin telah menduduki tanah tersebut sejak masa Jepang. Kemudian sebagian wilayah pekerbunan tatkala dinasionalisasi menjadi areal perkebunan PPN. Akan tetapi peristiwa 1965 menjadi dalih bagi pihak perkebunan untuk melakukan pengusiran rakyat tani. Atas dukungan Pertanu wilayah ini tetap dikelola oleh rakyat tani, berhasil diformalisasi tanah seluas 28,6 ha sebagai obyek Land reform dan resmi seluas 26,4 ha diredistribusi pada tahun $1968 .{ }^{54}$

Demikian pula penyelesaian tanah-tanah perkebunan dan kehutanan yang telah diduduki rakyat sejak masa Jepang: Perkebunan Kalikempit di Kecamatan Kalibaru, Perkebunan Sumberdadi di Kecamatan Pesanggaran, tanah kehutanan di Alas Tembakor Kecamatan Pesanggaran dan Sugihwaras di Glenmore. Persoalan ini sebenarnya telah mendapat perhatian Panitia Land reform Daerah Tingkat I Jawa Timur yang telah menerbitkan surat instruksi No. I/Agr/1211/XI/Lf/66 tentang Pelaksanaan Penyelesaian Tanah-tanah Perkebunan yang Diduduki/digarap Rakyat, tertanggal 19 September 1966. Secara tegas dikatakan bahwa dalam menyelesaikan persoalan tanah-tanah bekas perkebunan yang diduduki/digarap rakyat harus berpegang teguh pada UU dan peraturan yang ada. Namun di lapangan, instruksi ini diabaikan oleh pihak aparat keamanan sebagaimana dijelaskan di atas.

\section{Mencari keterkaitan}

Dari uraian di atas, saya ingin menarik beberapa kaitan sebagai berikut. Data olahan dalam tabel di bawah ini (lihat lampiran tabel 5) menjelaskan beberapa keterkaitan: pertama, dalam arti geografis, yakni terjadi konsentrasi pembunuhan massal (mass killing) di wilayah dengan tanah obyek Land reform terluas (perkebunan). Di sini proses primitive accumulation berdimensi vertikal, yakni suatu akumulasi disertai kekerasan yang terjadi di wilayah perkebunan akibat dari ketegangan hubungan vertikal antara pihak perusahaan perkebunan (di atas tanah negara dalam bentuk HGU) dengan rakyat, seperti yang bisa dilihat dari kasus tiga kecamatan ini.

Di kecamatan Pesanggaran, tanah obyek Land reform (TOL) perkebunan seluas 364,9 ha. Hasil pemilu 1955 menunjukkan bahwa pemilih PKI di Pesanggaran adalah terbesar se-Banyuwangi (19.134 orang). Pasca-1965, pembunuhan PKI di Pesanggaran sangat serentak. Sebagai contoh, hanya dalam hitungan sepuluh hari (10-20 Desember 1965), tercatat 111 jiwa meninggal.

Lalu di Kecamatan Gambiran, luas TOL perkebunan 317,4 ha. Di kecamatan ini terdapat peristiwa paling terkenal di Banyuwangi, yakni Peristiwa Cemethuk. Masyarakat membela diri dari serangan luar pemuda Muncar. Para penyerang tersebut dibunuh. Peristiwa yang besar lagi justru adalah aksi balasannya. RPKAD pada tanggal 20 Oktober 1965 menyisir wilayah

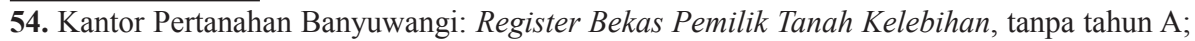
Register Land reform Kantor Pertanahan Banyuwangi, tanpa tahun B; Register Bekas Tanah Negara, tanpa tahun C. 
ini bersama pasukan gabungan "Gagak Hitam" dan Banser. Sayangnya tidak diperoleh catatan jumlah korban jiwa di wilayah ini. Penduduk yang dituduh terlibat G30S sebanyak 2.519 orang.

Total yang ditahan di Kalibaru, termasuk di dalamnya yang dibunuh, sebanyak 1.685 orang. Di wilayah ini terdapat sejumlah besar tanah obyek Land reform yang dirampas kembali oleh bekas pemiliknya untuk dijadikan HGU Perkebunan keluarga.

Kedua, dalam arti demografis, yakni terkait dengan kepadatan agraris (rasio penduduk dengan tanah). Lokasi tingginya kepadatan agraris adalah tempat konsentrasi terjadinya aksi sepihak, sehingga menjadi target penangkapan atau bahkan pembunuhan. Jumlah penduduk yang ditangkap berlokasi di berbagai kecamatan yang dijumpai banyak tanah absentee. Di sini primitive accumulation bersifat horisontal, yakni pengambil-alihan dan pengusiran oleh kelas agraris di pedesaan (antar-masyarakat). Bahkan tanah kelebihan di Wongsorejo seluas 171,5 ha terrekonsentrasi pada elit politik. Pada tahuntahun berikutnya tanah di wilayah ini justru diberikan HGU. Akibatnya masyarakat Wongsorejo mengalami kesulitan penghidupan (letting die) dan berjuang mengakses tanah secara marjinal. Bahkan hingga saat ini (2016) ketika masa HGU tersebut telah habis dan diterlantarkan, masyarakat yang telah menggarap tanah di wilayah konsesi tersebut mengalami kekerasan dan beberapa orang menjadi korban pemenjaraan. ${ }^{55}$

Wilayah TOL terluas kedua adalah di Kecamatan Genteng (131,764 ha) terhadap 339 petani penggarap. Terdapat pembunuhan penerima tanah Land reform dan perampasan tanah Land reform. Mereka yang ditangkap dan dituduh PKI sebanyak 4.122 orang.

Wilayah lain adalah kecamatan Singojuruh $(133,679$ ha) yang diredistribusi kepada 297 petani penggarap. Kasus yang menonjol dari wilayah ini adalah berhektar-hektar tanah dalam 14 bidang yang dihibahkan ke cucu pemiliknya agar terhindar dari Land reform sehingga menjadi obyek sengketa dengan kepala desa setempat.

Saat ini di Kabupaten Banyuwangi terdapat 9.390 orang lapar tanah dan masuk mengolah lahan dan bermukim di wilayah yang dinyatakan sebagai kawasan hutan, seluas 3.319,6 ha tanah (Kantor Pertanahan Banyuwangi, 2006). Terbentuk perkampungan baru dengan sarana yang sangat terbatas di wilayah ini. Perlu ditelusuri lebih lanjut kaitan asal muasal penduduk di wilayah ini dengan depopulasi pasca-1965. Jika dilihat lokasinya, pendudukan lahan ini terutama terjadi di Kecamatan Wongsorejo, Gambiran, Pesanggaran, dan Tegaldlimo, yang notabene adalah lokasi di mana penduduk mengalami kekerasan dan perampasan tanah pasca-1965. Proses terjadinya pendudukan lahan, pembentukan kampung, dan perjuangan masyarakat di dalam mengakses tanah dan melawan penyingkiran fisik maupun sosial ini memerlukan penelitian lebih lanjut.

55. membunuhindonesia.com (2016). 


\section{Penutup}

Telah dibahas kaitan antara pelaksanaan kebijakan Land reform, kekerasan, dan tindakan counter-Land reform berbagai bentuk mulai dari perampasan tanah, pengusiran, ancaman dan pembelian paksa tanah dengan harga murah. Berbagai tindakan itu dilakukan oleh sipil dan militer. Land reform berhasil mengoreksi ketimpangan penguasaan tanah atau mengurangi kepadatan agraria. Akan tetapi kekerasan pasca-1965 membalik proses tersebut dan menjadikan kekerasan itu sebagai jalan lempang bagi proses akumulasi berikutnya, baik yang dilakukan secara horisontal maupun vertikal. Apa yang terjadi pasca-1965 adalah pemisahan secara brutal petani dari alat produksi dan ruang hidupnya (tanah) yang terjadi melalui pembunuhan dan pengusiran. Mereka tidak lagi menjadi petani pemilik namun buruh pertanian atau bahkan terusir dari wilayah pertanian-pedesaan dan masuk ke wilayah-wilayah baru dengan penuh resiko pengusiran, seperti yang saat ini terjadi pada mereka yang menduduki lahan dalam kawasan hutan. Pemisahan fisik dan sosial, kontrol dan stigma, serta pengabaian hak-hak kewarganegaraan mereka direproduksi oleh rezim keagrariaan baru sekarang ini.

Secara historiografis kita perlu menggeser titik tolak dalam membuat kronologi dan mengonstruksi sejarah Indonesia 1965. Dalam kajian sejarah agraria, prosesnya tidak tiba-tiba dipotong dari terjadinya 'aksi sefihak' di pedesaan (meski menyadari istilah 'sefihak' ini bermasalah). Namun, harus dibaca dalam dinamika panjang perjuangan perebutan sumberdaya agraria sejak masa kolonial/feodal menuju nasional untuk kepentingan rakyat Indonesia. Jika dibaca secara demikian, maka usia perjuangan kemerdekaan berbasis sumberdaya agraria (tanah-air Indonesia) itu pendek saja, karena terhenti oleh kekerasan 1965 sebagai prolog-nya, dan akumulasi primitif sebagai nalog-nya. Kebijakan terhadap modal asing (1967), penguasaan sumberdaya hutan (UU Pokok Kehutanan 1967), pengelolaan HGU dan legalisasi aset tanah tanpa disertai penataan ulang melalui Land reform, menjadi pilihan rezim kekuasaan Orde Baru berikutnya. Pembangunan ekonomi berbasis sumberdaya agraria berorientasi segelintir orang / konglomerasi dalam konteks perluasan kapital inilah justru telah menjadi epilog perjalanan sejarah agraria Indonesia saat ini.

Artikel ini menyisakan beberapa pertanyaan yang baru bisa dijawab dengan studi dan bukti-bukti lebih terinci, seperti seberapa jauh pelaksanaan Land reform mengoreksi ketimpangan agraria dan berapa persentase pelaksanaan Land reform tersebut terhadap total komposisi demografis-geografis di Banyuwangi. Di Kecamatan Wongsorejo, Gambiran, Pesanggaran, dan Tegaldlimo, saat ini terdapat hampir sepuluh ribu jiwa penduduk yang bermukim di tanah yang dikategorikan dalam kawasan hutan. Kaitan mereka ini dengan depopulasi pasca-1965 penting dikaji lebih lanjut. 

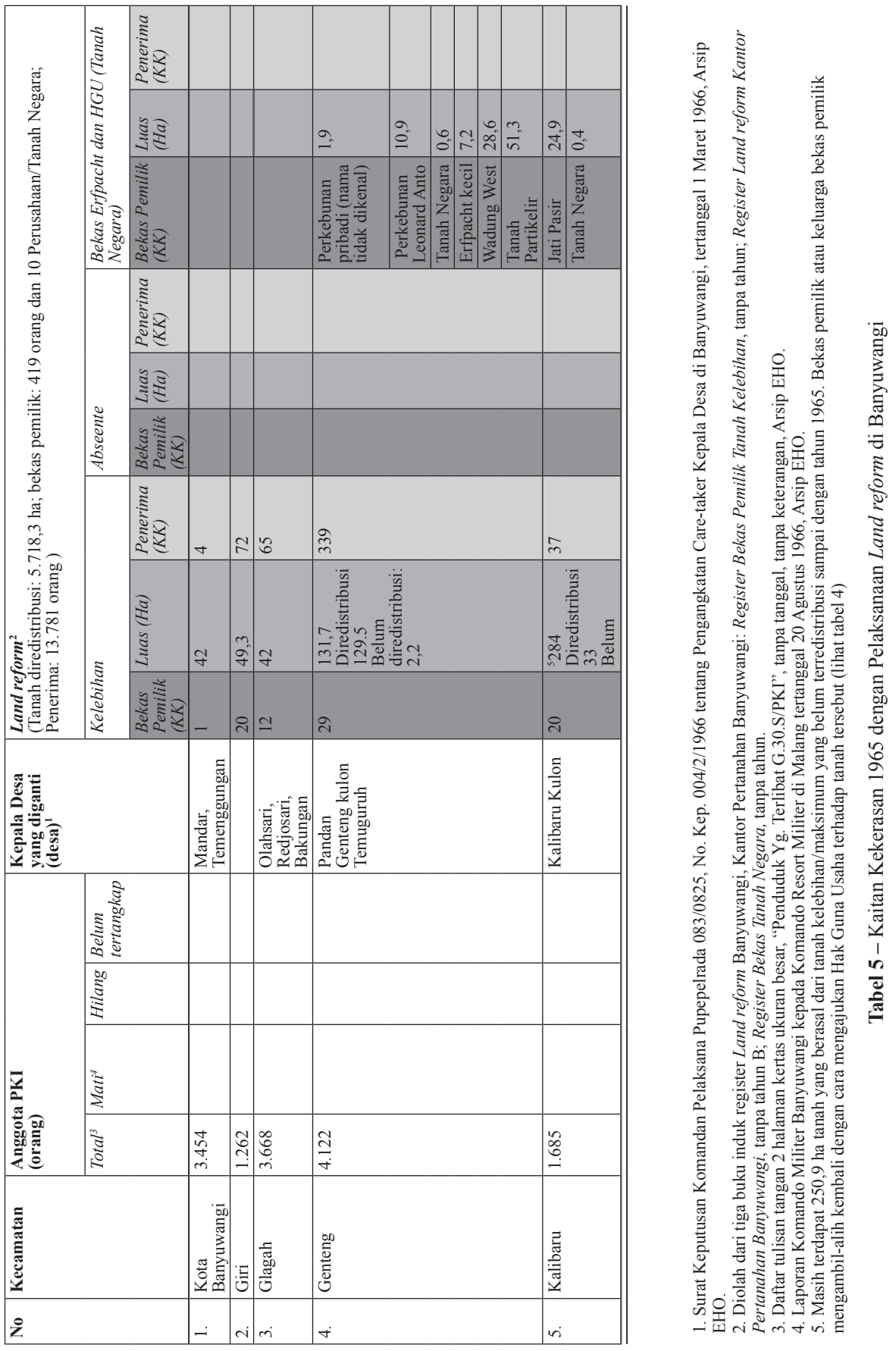


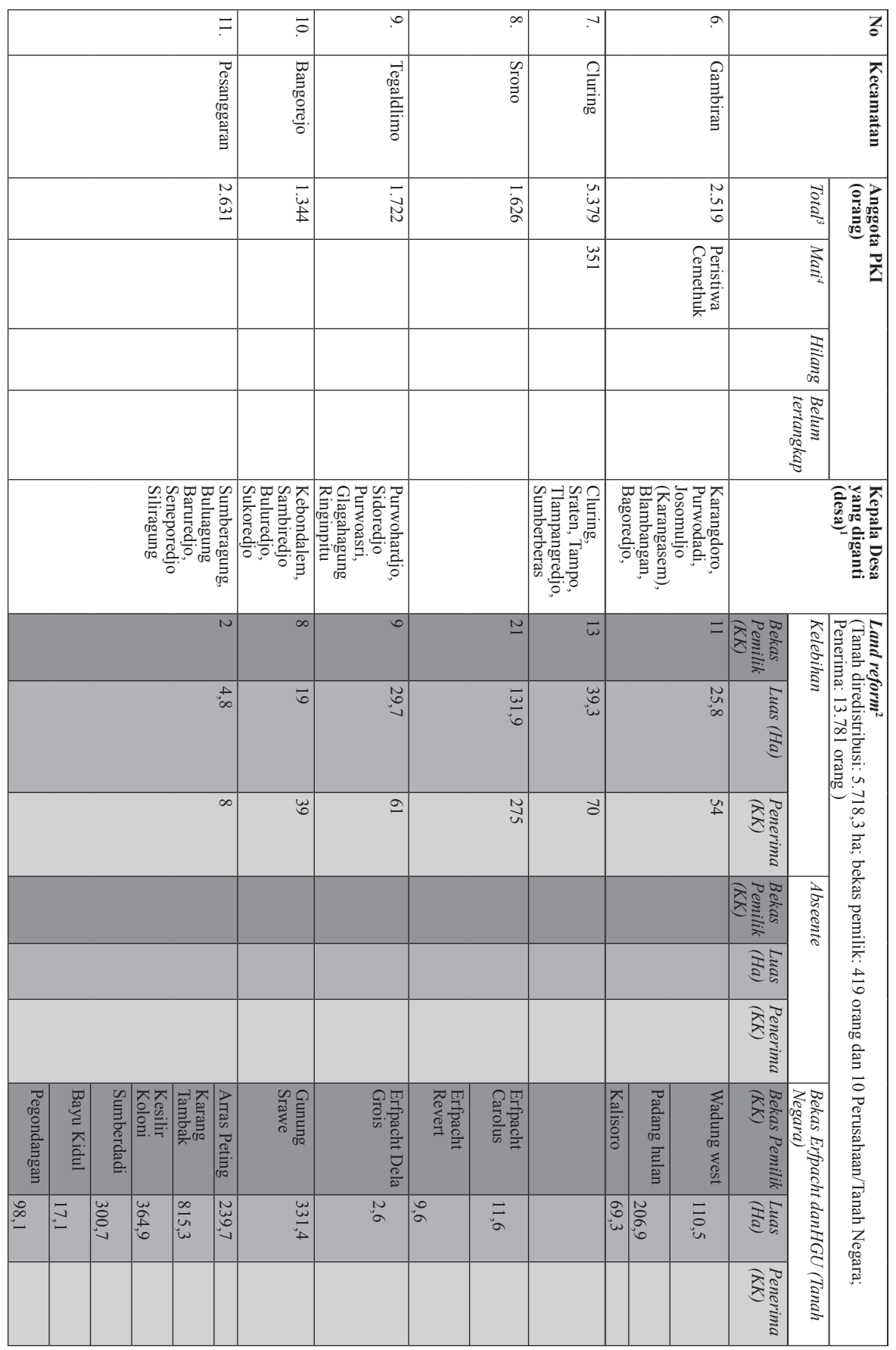




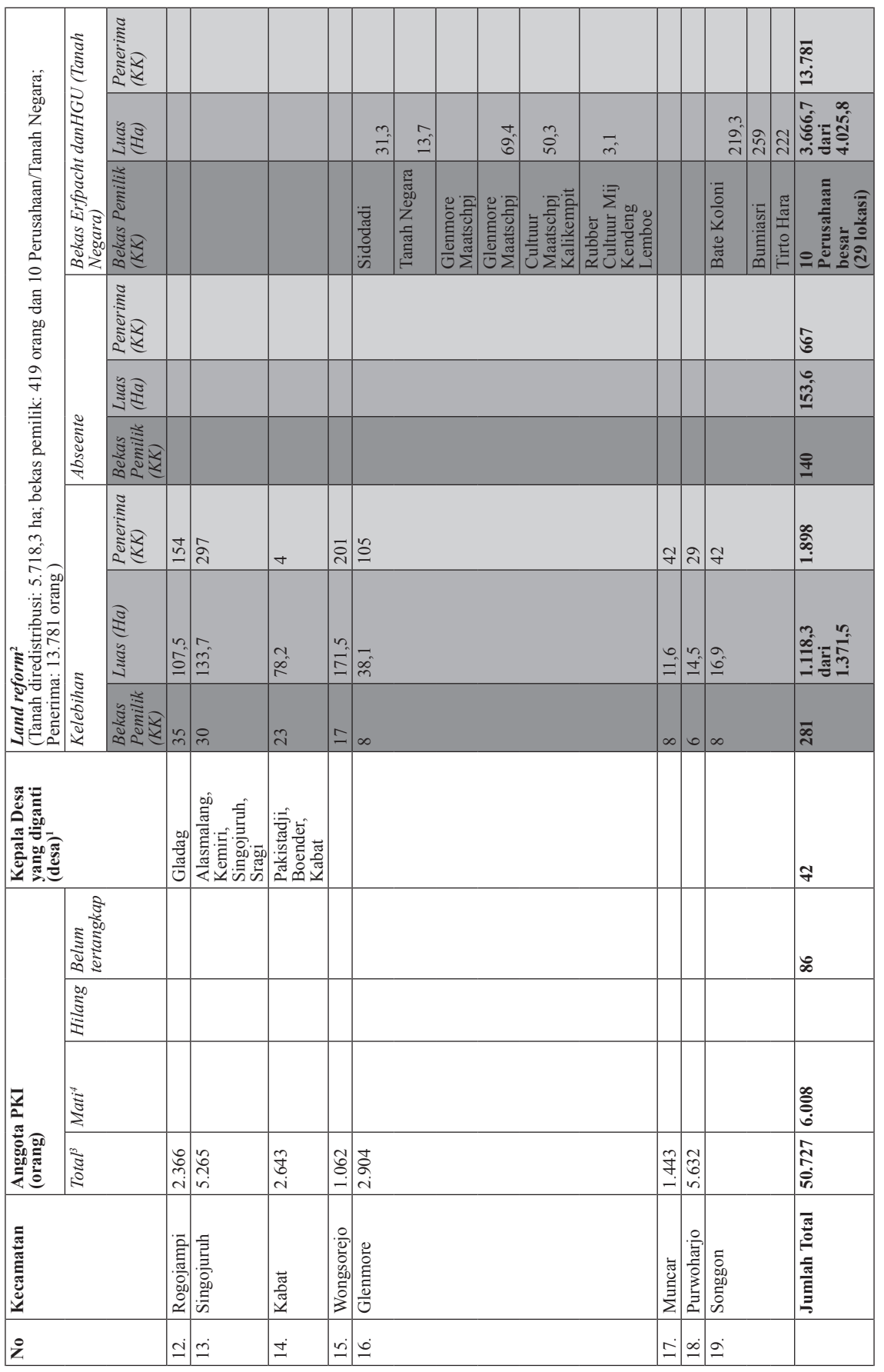




\section{Daftar Pustaka}

\section{Arsip}

Daftar tulisan tangan 2 halaman kertas ukuran besar, "Penduduk Yg. Terlibat G.30.S/PKI", tanpa tanggal, tanpa keterangan.

Daftar yang disusun oleh Asisten Wedana Pesanggaran, "Daftar Adanja Orang2 Jang Meninggal Dunia Akibat Terlibat G.30.S dalam Daerah Ketjamatan Pesanggaran, mulai tanggal 10 s/d 20 Desember 1965", tanggal 15 (sic.) Desember 1965.

Daftar yang disusun oleh Komandan Kodim 0825/7, Kecamatan Cluring, "Rekapitulasi ExPKI dalam Ketjamatan Tjluring”, 5-7-1968.

Dokumen militer ratusan lembar disimpan secara partikulir dan belum dikatalogisasi oleh Komunitas Etnohistori yang berkedudukan di Yogyakarta, dengan kode: Arsip EHO.

Dokumen, 6 Maret 1966.

Dua laporan (24 halaman) Kepala Biro Tahanan Pelaksana Pupepelrada 083/0825 kepada Kepala Staf Pelaksana Pupepelrada 083/0825, tanggal 17 November 1965.

Kantor Pertanahan Banyuwangi, Register Bekas Pemilik Tanah Kelebihan, tanpa tahun A.

Kantor Pertanahan Banyuwangi, Register Land reform Kantor Pertanahan Banyuwangi, tanpa tahun B.

Kantor Pertanahan Banyuwangi, Register Bekas Tanah Negara, tanpa tahun C.

Laporan anggota Puterpra, 21 Februari 1966.

Laporan anggota Puterpra, 23 Maret 1966.

Laporan Kepala Staf Komandan Distrik Militer 0825, "Laporan Singkat Situasi Terachir KODIM 0825/Banjuwangi”, 22 September 1966.

Laporan Pasi I, Komando Distrik Militer 0825, Pelda Djoemangat, pada Rapat Seksi I Korem 083 di Pasuruan, 14 Juli 1966.

Laporan petugas Urusan Teritorial \& Perlawanan Rakyat 0825/IX kepada Komandan Distrik Militer 0825/Koordinator I, Banyuwangi, "Daftar adanja barang2 milik orang2 jg tersangkut G.30.S”, tanggal 21 Maret 1966.

Laporan Pos Kepolisian Muncar, 9 Juli 1966.

Laporan satu bundel (71 halaman) dari Komandan Korem 0825 Kecamatan Gambiran tentang “Rekapitulasi Anggota PKI jang Masuk Daftar 'F' Ketjamatan Gambiran”, 2 Juli 1968.

Laporan seorang anggota Puterpra tentang Situasi Daerah Kalibaru Mengenai Politik/ Keamanan, 1 Februari 1966.

Laporan seorang guru kepada Komandan Pelaksana Pupepelrada Dati II Banyuwangi, dengan lampiran bukti-bukti berbagai dukungan terhadap rekan guru yang dituduh PKI, 4 Juli 1966.

Laporan Situasi Daerah Puterpra 0825/IX Tegaldlimo, tanggal 7 Maret 1966.

Surat deposisi seorang letnan dua, 11 Desember 1965.

Surat Keputusan Komandan Pelaksana Pupepelrada tertanggal 1 Maret 1966.

Surat pengakuan, 9 Desember 1965.

Surat Pertanu Banyuwangi, 23 Juni 1966.

Surat seorang Serda polisi kepada Komandan Sektor Kepolisian Kecamatan Singojuruh, perihal "Menuntut diri seorang Kepala Desa Songgon pribadi karena merampas hak milik tanah sawah milik orang lain tanpa idjin", 17 November 1966.

Surat yang mengatasnamakan "Rakjat DATI II Banjuwangi" tertanggal 11-11-1965 ditujukan kepada seorang Pelaksana Pupepelrada Banyuwangi.

Surat, 22 Februari 1966.

"Turunan daftar coordinator Dosen dan Petugas CSS PKI Rogodjampi”, tanpa tanggal. 


\section{Koran}

Antara, "BTI Masih Lakukan Aksi2 Sepihak, sering mendjadi aksi2 bakar rumah, rampas hasil produksi \& lain2 pengatjauan. Di Banjuwangi setiap hari ada aksi2 sepihak", 5 Januari 1965.

Kompas, "Tanah Redistribusi Landreform, Epilog Gestok", 21 Februari 1966.

Membunuhindonesia.net, "Sengketa Lahan Petani Kampung Bongkoran dengan PT

Wongsorejo", 2016.

Merdeka.com, "Wisata sejarah di Monumen Lubang Buaya Cemetuk Banyuwangi", 7 Mei

2016.

Suara Indonesia, 4 Januari 1965.

\section{Buku, Jurnal, Laporan}

Achdian, Andi, Tanah Bagi Yang Tak Bertanah: Land reform Pada Masa Demokrasi Terpimpin. Bogor dan Yogyakarta: Kekal Press dan STPN, 2008.

Anonim, "Report from East Java", Indonesia 41, 1986, hlm. 134-149.

Anonim, Polemik Merdeka Harian Rakjat/dengan kata pengantar Nyoto dan kata akhir Sukarno. Jakarta: Harian Rakjat, 1964.

Atma, Galih Widhi, Hinduisasi Masyarakat Desa Kaligondo Kecamatan Genteng Kabupaten Banyuwangi Tahun 1965-1985, Skripsi Ilmu Sejarah, Universitas Jember, 2012.

Cribb, Robert (ed.), Pembantaian PKI di Jawa dan Bali 1965-1966. Yogyakarta: Mata Bangsa, 2003 (edisi asli, Monash, 1990).

Crouch, Harold, The Army and Politics in Indonesia. Jakarta: Equinox Publishing, 2007 (edisi pertama 1978).

Farid, Hilmar, "Indonesia's Original Sin: Mass Killing and Capitalist Expansion, 1965-1966", Inter-Asia Cultural Studies 6(1), 2005, hlm. 3-16.

Farid, Hilmar "Menuju Sejarah/Geografi Agraria", kata pengantar untuk working paper, Hilmar Farid dkk., Sejarah Geografi Agraria. Jakarta dan Yogyakarta: Institut Sejarah Sosial Indonesia dan Sekolah Tinggi Pertanahan Nasional, 2013, hlm. 1-10.

Hefner, Robert W., Geger Tengger, Perubahan Sosial dan Perkelahian Politik. Yogyakarta: LkiS, 1999 (edisi asli, Princeton University Press, 1990).

Ikaningtyas, "Pelenyapan Kaum Kiri Banyuwangi”, http://ikaningtyas.blogspot.co.id/2015/10/ pelenyapan-kaum-kiri-banyuwangi.html, diakses pada 23 Oktober 2016.

Ismet, Daftar Tanah Perkebunan di Indonesia. Jakarta: Biro Sinar, 1970.

Jenkins, David \& D. Kammen, "The army para-commando regiment and the reign of terror in Central Java and Bali", dalam D. Kammen and K. McGregor (eds), The contours of mass violence in Indonesia, 1965-68. Singapore: NUS Press and NIAS Press, 2012, hlm. $75-103$.

Kantor Pertanahan Banyuwangi, "Kawasan Hutan yang Menjadi Sengketa dengan Masyarakat", laporan 26 Februari 2006.

Kasdi, Aminuddin, Kaum Merah Menjarah: Aksi Sepihak PKI/BTI di Jawa Timur 1960-1965. Yogyakarta: Jendela, 2001.

Kasdi, Aminuddin, "Aksi Sepihak di Ngawi Jawa Timur", dalam Taufik Abdullah dkk (ed.), Malam Bencana 1965 dalam Belitan Krisis Nasional: Bagian II Konflik Lokal, Jilid 2. Jakarta: Yayasan Pustaka Obor Indonesia, 2011, hlm. 222-304.

Klinken, Helene van (ed.), Final Report of the International People's Tribunal on Crimes against Humanity in Indonesia 1965 (dwibahasa). Amsterdam dan Bandung: IPT 65 Foundation dan Ultimus, 2017. 
Krisnadi, I.G., “Amuk Massa Cemethuk Banyuwangi 1965”, Jurnal Ilmu Pengetahuan Sosial 7, 2007, hlm. 1-13.

Li, Tania Murray, "To Make Live or Let Die? Rural Dispossession and the Protection of Surplus Populations", Antipode 41 (1), 2009, hlm. 66-93.

Luthfi, Ahmad Nashih, "Sejarah dan Revitalisasi Perjuangan Pertanian Nahdlatul Ulama Melawan Ketidakadilan Agraria", Bhumi 3 (2), November 2017, hlm. 145-59.

Luthfi, Ahmad Nashih, Razif, dan M. Fauzi, (kolaborasi chronic design dengan Alit Ambara), Kronik Agraria Indonesia, Memperluas Imajinasi Lintas Sektor dan Aktor. Yogyakarta, Bogor, Jakarta: STPN, Sajogyo Institute, ISSI, 2011.

Lyons, Margo, "Dasar-dasar Konflik di daerah Pedesaan Jawa", dalam Sediono M.P. Tjondronegoro dan Gunawan Wiradi (eds.), Dua Abad Penguasaan Tanah. Jakarta: Yayasan Pustaka Obor Indonesia, 1984, hlm 168-236.

Marx, Karl, Kapital, sebuah Kritik Ekonomi Politik, Buku I: Proses Produksi Kapitalis secara Menyeluruh. Jakarta: Hasta Mitra, 2004 (edisi asli, Moscow, 1959).

Mustafa, Hanif Risa, Konflik Elit dan Kekerasan Arus Bawah: Pergolakan Politik 1965 di Banyuwangi, Tesis S-2, Program Studi Ilmu Sejarah. Universitas Gadjah Mada, 2015.

Notosusanto, Nugroho, "Kisah Kejadian", dalam Notosusanto, Nugroho dan Ismail Saleh, Tragedi Nasional Percobaan Kup G-30-S/PKI di Indonesia. Jakarta: Intermasa, 1989.

Nugroho, Singgih, Menyintas dan Menyeberang: Perpindahan Massal Keagamaan Pasca 1965 di Pedesaan Jawa. Yogyakarta: Syarikat, 2008.

Nugroho, Uji, "Memutihkan yang Merah: Ujian Guru Agama (UGA) dan Deidelogisasi Komunis di Gunung Kidul Pasca-1965", dalam Sri Margana dan Widya Fitrianingsih (ed.), Sejarah Indonesia: Perspektif Lokal dan Global. Yogyakarta: Ombak dan Jurusan Sejarah UGM, 2009, hlm. 408-429.

Purnama, Priya, Konflik Berdarah di Desa Karangasem Kecamatan Gambiran Kabupaten Banyuwangi (18 Oktober 1965), Skripsi Ilmu Sejarah, Universitas Jember, 2012.

Robinson, Geoffrey, Sisi Gelap Pulau Dewata, Sejarah Kekerasan Politik. Yogyakarta: LkiS, 2006 (edisi asli, Cornell University Press, 1995).

Roosa, John, "Pengetahuan tentang Sebuah Rahasia Umum: Penghilangan Massal 1965-66 di Indonesia", Institute Sejarah Sosial Indonesia, online (artikel asli: The State of Knowledge about an Open Secret: Indonesia's Mass Disappearances of 1965-66", Journal of Asian Studies 75 (2), 2016) http://www.tribunal1965.org/id/pengetahuan-tentang-sebuahrahasia-umum-penghilangan-massal-1965-66-di-indonesia/, diakses 12 Juli 2016

Setiawan, Hersri, Kamus Gestok. Yogyakarta: Galang Press, 2003.

Shohibuddin, Mohamad dan Ahmad Nashih Luthfi, Land reform Lokal a La Ngandagan, Inovasi Sistem Tenurial Adat di Sebuah Desa Jawa, 1947-1964. Yogyakarta: Sekolah Tinggi Pertanahan Nasional, 2010.

Simpson, Bradley R., Economist with Guns, Authoritarian Development and US-Indonesian Relations, 1960-1968. Stanford: Stanford University Press, 2008.

Soekarno, "Tentang Polemik Tavip", dalam Anonim, Polemik Merdeka Harian Rakjat/dengan kata pengantar Nyoto dan kata akhir Sukarno. Jakarta: Harian Rakjat, 1964, hlm. 210, 212-213.

Sulistyo, Hermawan, Palu Arit di Ladang Tebu: Sejarah Pembantaian Massal yang Terlupakan (1965-1966). Jakarta: Kepustakaan Populer Gramedia, 2000.

Tamara, Mohamad Nasir, "Studi Indonesia (dan Asia Tenggara) di Amerika Serikat serta Pengaruh 'American Way of Thinking'", Archipel 33, 1987, hlm. 17-56.

Tat, Oei Tjoe, Memoar Oei Tjoe Tat: Pembantu Presiden Soekarno. Jakarta: Hasta Mitra, 1995.

Wieringa, Saskia E., Penghancuran Gerakan Perempuan di Indonesia. Jakarta: Garba Budaya dan Kalynamitra, 1999. 


\section{Wawancara}

Ichwan, Srono, Banyuwangi, 5 Oktober 2016.

Suhalik, Giri, Banyuwangi, 6 Oktober 2016.

Bambang Ruswanto, Genteng, Banyuwangi, 5 Oktober 2016. 
